\title{
Regioselectivity of the conjugate addition of amines to dissymmetrical pull-pull alkenes
}

Dr. Alexander Yu. Rulev, ${ }^{*[a]}$ Ilya N. Zubkov, ${ }^{[a]}$ Dr. Igor A. Ushakov, ${ }^{[a]}$ Dr. Valentin A. Semenov, ${ }^{[\mathrm{a}]}$ Dr. Alexander V. Vashchenko, ${ }^{[\mathrm{a}]}$ and Dr. Jacques Maddaluno*[b]

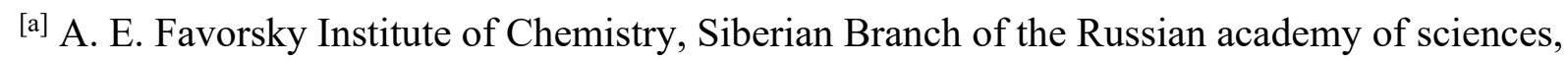
Irkutsk 664033, Russia; e-mail: rulev@irioch.irk.ru

${ }^{[b]}$ Normandie Université, UNIROUEN, INSA de Rouen, CNRS, Laboratoire COBRA (UMR 6014 \& FR 3038), 76000 - Rouen (France); e-mail: jmaddalu@,crihan.fr

To the memory of Dr. Lucette Duhamel (1935 - 2020). Two of us have had the honour and pleasure to work with this outstanding scientist (as a CNRS Chargé de Recherches (JM) and NATO grant scholar (AR)) in the Laboratoire des Fonctions Azotées et Oxygénées Complexes of the Rouen University, France.

\begin{abstract}
The regioselectivity of the conjugate nucleophilic addition of amines to vicinal diacceptor-substituted alkenes has been studied. A set of results obtained with standard primary and secondary amines gives some clues on the relative acceptor character of classical electronwithdrawing groups (EWG). We have shown in addition that computed inverse local nucleophilicity index can be used to predict the regioselectivity of the nucleophilic attack.
\end{abstract}

Keywords: aza-Michael reaction, vicinal substituted electron-deficient alkenes, nitrogen nucleophiles, regioselectivity

\section{Introduction}

The aza-Michael addition is one of the most powerful tools to create a new carbon - nitrogen single bond in one step and often with high selectivity. ${ }^{[1]}$ Taking into account the fact that each seventh reaction in pharmaceutical industry involves the formation of at least one $\mathrm{C}-\mathrm{N}$ bond, it is not surprising that this reaction is especially valuable for the synthesis of bioactive compounds and drugs. ${ }^{[2]}$ In fact, it is one of the simplest and most efficient strategies to prepare $\beta$-amino acids and their derivatives from readily available starting materials. Moreover, aza-Michael reaction can initiate a transformation cascade to afford complex heterocyclic molecules in one single step (the so-called aza-Michael-Initiated Ring Closure (aza-MIRC) methodology). ${ }^{[1 \mathrm{~b}-\mathrm{d}, 3,4]}$ 
In general, the conjugate addition of nitrogen nucleophiles to electron-deficient olefins proceeds through a stepwise mechanism, including the formation of zwitterionic intermediates. The feature of initial amine and the nature of Michael acceptor or solvent influence both kinetics and reaction mechanism. ${ }^{[5]}$. The protic solvents such as alcohols have been reported to favour this transformation and Lewis acids (such as dihalogens or certain transition or main-group metals salts) proved to be one of the most efficient catalysts. ${ }^{[1 b, 6]}$

Traditionally, the conjugate addition of amines to olefins substituted by an electrondeficient appendage proceeds under strongly acidic or basic conditions and generates a new $\mathrm{C}-\mathrm{N}$ bond selectively at the $\beta$-position of the Michael acceptor. If a second EWG is introduced gem to the first one ( $\alpha, \alpha$-disubstituted olefin), the reactivity tends to increase and a similar regioselective addition is expected at the $\beta$ position. ${ }^{[7]}$ In contrast, if a second group is added onto the vicinal position of the double bond ( $\alpha, \beta$-disubstituted olefin) the situation is not as straightforward since the nucleophilic attack can now take place on both olefinic carbons. Thus, the regioselectivity of the addition on olefins $\mathbf{1}$ becomes a question of interest since the competing bond polarizations rely on an entangled combination of inductive, mesomeric, hyperconjugative and steric effects and both isomeric adducts 2 and 3 can a priori be obtained (Scheme 1). Obviously, the 2/3 ratio will depend on the acceptor ability of both functional groups (kinetic control) as well as on the relative stability of the zwitterions formed during the first step (thermodynamic control).

Scheme 1. Regioselective nucleophilic addition to vicinal disubstituted alkenes

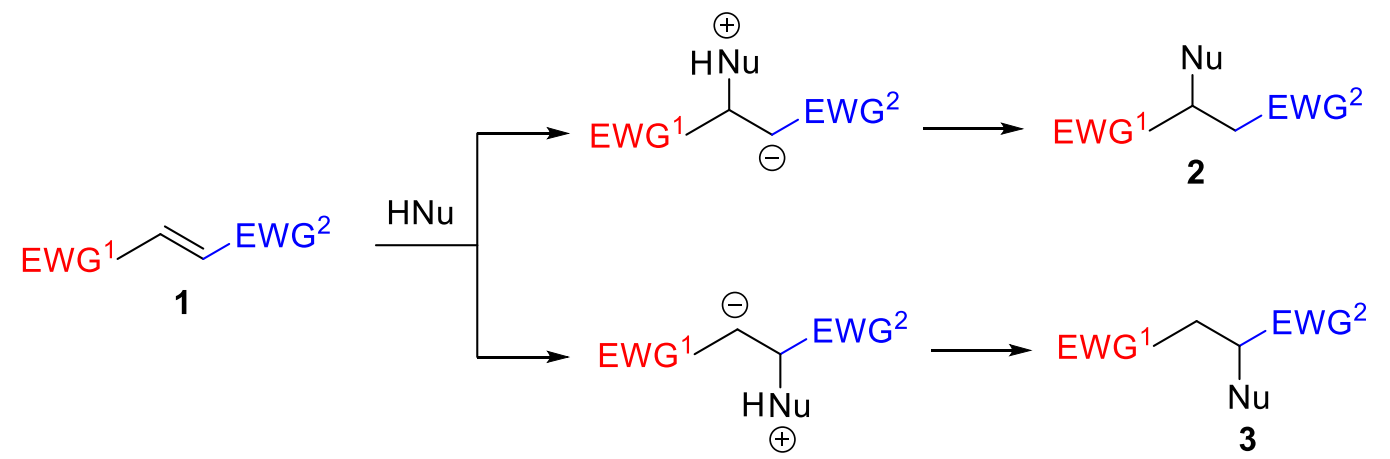

Doubly activated olefins bearing two different electron-withdrawing groups in vicinal position (so-called pull-pull olefins) ${ }^{[1 b, 8]}$ could a priori be regarded as highly reactive compounds 
because of their global electron depletion. However, a few articles published during the last decades on the reaction of nucleophiles on such derivatives (Scheme 2) bars generalization. ${ }^{[9-23]}$ It was nevertheless demonstrated that several nitrogen nucleophiles add to $\beta$-nitroalkenoates to afford exclusively $\alpha$-amino esters. ${ }^{[9-16]}$ An analogous regioselectivity was observed when acrylic acid derivatives bearing a carbonyl group at the $\beta$-position were treated with primary or secondary amines. ${ }^{[17-19]}$ On the contrary, only $\beta$-amino acid derivatives were formed in the reactions of amines or $\mathrm{N}, \mathrm{N}$ - and $\mathrm{N}, \mathrm{O}$-binucleophiles with $\beta$-trifluorocrotonic acid derivatives. ${ }^{[20-22]}$ Finally, the aza-Michael addition of some primary amines and azoles to unsymmetrical fumaric esters led to the formation of the regioisomers mixture. ${ }^{[23]}$

Scheme 2. Previous results on the regioselectivity of aza-Michael addition. The citation references are given in square brackets.

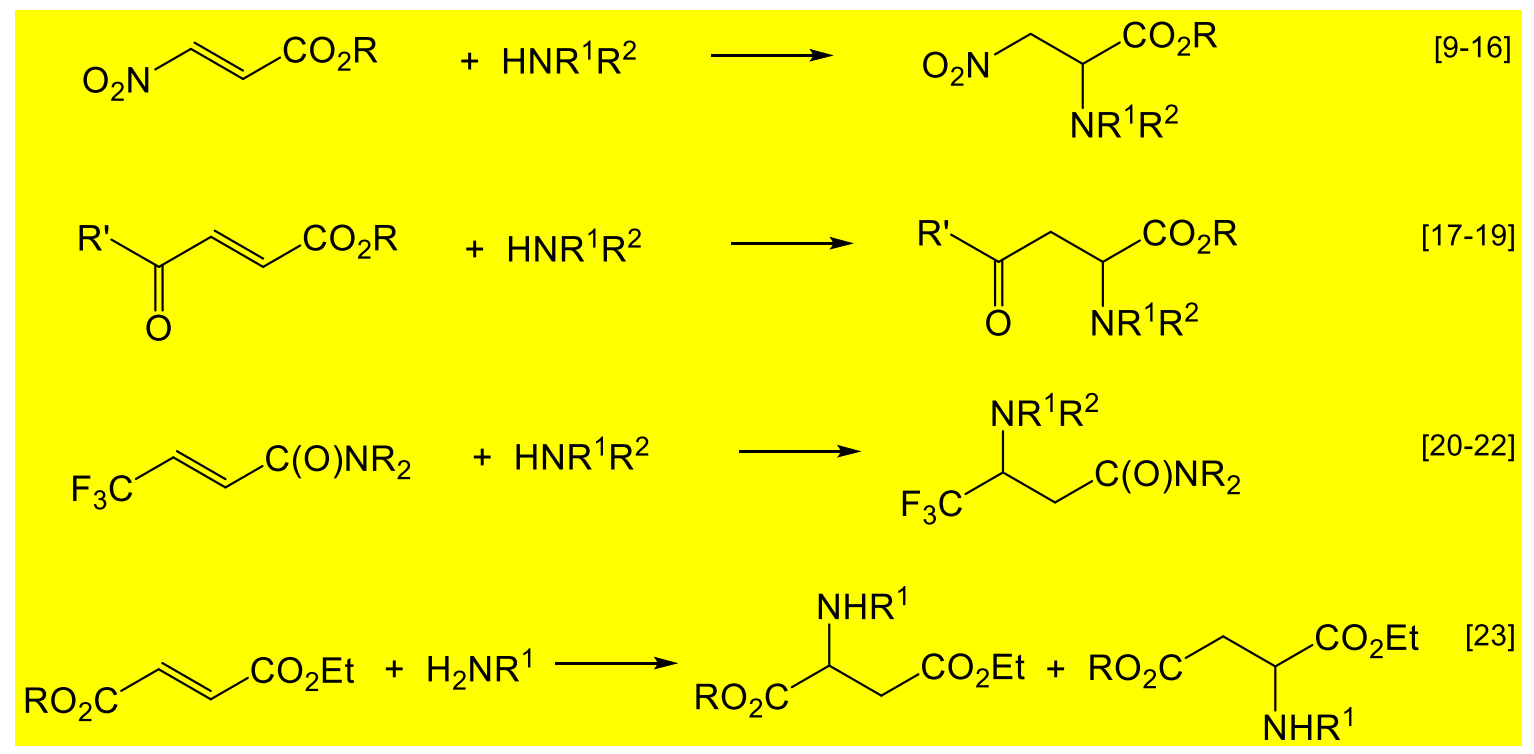

The paucity of results in this field and the differences between the published reaction conditions make the prediction of the regioselectivity of the addition to unsymmetrical alkenes containing two vicinal EWG groups difficult. Relying on the chemist's intuition being unsatisfactory to current standards, we considered that more research in this field was needed to predict the regioselectivity of the nucleophilic attacks on these systems. We present here the results of a series of model reactions on the nucleophilic addition of amines to Michael acceptors bearing 
two electron-withdrawing groups in vicinal position, all run following similar protocols to get fully comparable results. Two general sets of conditions were tested for the addition: "classical" or hyperbaric (16 kbar) conditions, both at room temperature in a protic solvent (methanol or ethanol). We and others ${ }^{[24-28]}$ have indeed shown before that pressure exerts a major influence on the course of aza-Michael reactions.

\section{Results and Discussion}

Benzylamine (a prototypical primary amine) and morpholine (a secondary one) were chosen as standard models of highly nucleophilic reagents. To avoid side reactions, strong bases such as lithium amides were excluded from the study.

We firstly examined the reaction of these nucleophiles with commercially available disubstituted alkenes (E)-1a,b and (Z)-1c under catalyst-free conditions. As detailed underneath, we found that the reaction of equimolar quantities of these alkenes and amines $\mathbf{2 a , b}$ performed remarkably well at room temperature and atmospheric pressure in a protic solvent, here methanol or ethanol, affording $\alpha$-and/or $\beta$-amino esters 3 and $\mathbf{4}$ in good to excellent yields (Table 1). Protic solvents are known to be more partners than just solvents in this type of addition. ${ }^{[4,24,25]}$

We began the study with trifluoromethylated acrylate $(E)-\mathbf{1 a}$, an olefin in which a pure $\sigma$ attracting group $\left(\mathrm{CF}_{3}\right)$ competes with a conjugated ester appendage. In standard conditions, 1a undergoes a regioselective nucleophilic attack of the primary and secondary amines $\mathbf{2 a , b}$ and affords, as predicted from literature, ${ }^{[20]} \beta$-amino esters 3aa and 3ab. Their structure was unambiguously determined by ${ }^{13} \mathrm{C}$ NMR: the presence of a quartet at $62.6 \mathrm{ppm}\left({ }^{2} J_{\mathrm{CF}}=26.4 \mathrm{~Hz}\right.$ for 3aa) or at $56.4 \mathrm{ppm}\left({ }^{2} J_{\mathrm{CF}}=28.0 \mathrm{~Hz}\right.$ for 3ab $)$ indicates that the $\mathrm{CHNR}{ }^{1} \mathrm{R}^{2}$ moiety is directly connected to the trifluoromethyl group. The yield of the reaction could be increased, even at room temperature and both in protic and aprotic solvents, provided high pressures were applied: under $16 \mathrm{kbar}$, the reaction with morpholine led to 3aa in up to $99 \%$ yield and unaltered regioselectivity (Table 1, entries 1-4). ${ }^{[26]}$ The chiral secondary dibenzylic amine $2 \mathbf{c}$ was also successfully tested in 
the hyperbaric version of this reaction. It afforded the corresponding target aza-Michael adduct 3ac in high yield, a compound that, unfortunately, is not very stable and decomposed through a rapid retro-aza-Michael reaction upon purification (Table 1, entry 5). We did not insist on determining the diastereoselectivity of this reaction since it is expected to be disappointing. ${ }^{[27]}$

Table 1. Reaction of $\beta$-acceptor-substituted enoates with amines.

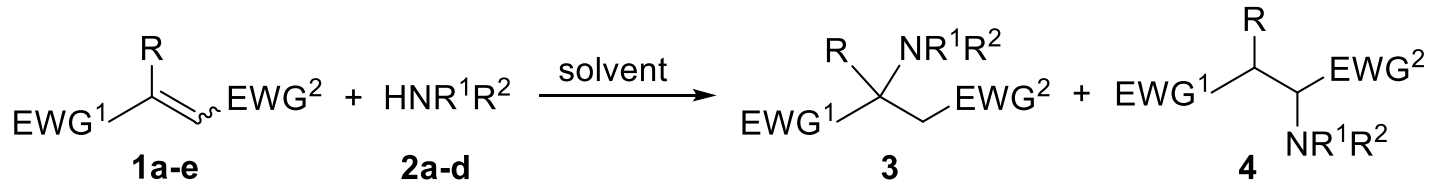

\begin{tabular}{|c|c|c|c|c|c|c|c|}
\hline \multirow{2}{*}{ \# } & \multicolumn{4}{|c|}{ Michael acceptor $\mathbf{1}$} & \multirow{2}{*}{ Amine 2} & \multirow{2}{*}{ Exp. conditions } & \multirow{2}{*}{$\operatorname{Pdt}(\%)^{\mathrm{a}}$} \\
\hline & $\mathrm{EWG}^{1}$ & $\mathrm{EWG}^{2}$ & $\mathrm{R}$ & & & & \\
\hline 1 & $\mathrm{CF}_{3}$ & $\mathrm{CO}_{2} \mathrm{Et}$ & $\mathrm{H}$ & (E)-1a & Morpholine (2a) & $\mathrm{EtOH}, \mathrm{rt}, 72 \mathrm{~h}$ & 3aa (70) \\
\hline 2 & $\mathrm{CF}_{3}$ & $\mathrm{CO}_{2} \mathrm{Et}$ & $\mathrm{H}$ & $(E)-\mathbf{1 a}$ & Morpholine (2a) & EtOH, rt, 16 kbar, 24 h & $3 \mathbf{a a}(96)$ \\
\hline 3 & $\mathrm{CF}_{3}$ & $\mathrm{CO}_{2} \mathrm{Et}$ & $\mathrm{H}$ & $(E)-\mathbf{1 a}$ & Morpholine (2a) & THF, rt, 16 kbar, 24 h & 3aa (99) \\
\hline 4 & $\mathrm{CF}_{3}$ & $\mathrm{CO}_{2} \mathrm{Et}$ & $\mathrm{H}$ & $(E)-\mathbf{1 a}$ & Benzylamine (2b) & EtOH, rt, $72 \mathrm{~h}$ & $\mathbf{3 a b}(90)$ \\
\hline 5 & $\mathrm{CF}_{3}$ & $\mathrm{CO}_{2} \mathrm{Et}$ & $\mathrm{H}$ & $(E)-\mathbf{1 a}$ & $\mathrm{PhCH}(\mathrm{Me}) \mathrm{NHBn}(\mathbf{2})$ & EtOH, rt, 16 kbar, 24 h & $\operatorname{3ac}(95)^{\mathrm{b}}$ \\
\hline 6 & $\mathrm{MeC}(\mathrm{O})$ & $\mathrm{CO}_{2} \mathrm{Me}$ & $\mathrm{H}$ & $(E)-\mathbf{1 b}$ & Morpholine (2a) & EtOH, rt, $72 \mathrm{~h}$ & 4ba (98) \\
\hline 7 & $\mathrm{MeC}(\mathrm{O})$ & $\mathrm{CO}_{2} \mathrm{Me}$ & $\mathrm{H}$ & $(E)-\mathbf{1 b}$ & Morpholine (2a) & $\mathrm{MeOH}, \mathrm{rt}, 16 \mathrm{kbar}, 24 \mathrm{~h}$ & 4ba (57) \\
\hline 8 & $\mathrm{MeC}(\mathrm{O})$ & $\mathrm{CO}_{2} \mathrm{Me}$ & $\mathrm{H}$ & $(E)-\mathbf{1 b}$ & Benzylamine (2b) & $\mathrm{EtOH}, \mathrm{rt}, 72 \mathrm{~h}$ & $4 b b(57)$ \\
\hline 9 & $\mathrm{CN}$ & $\mathrm{CO}_{2} \mathrm{Et}$ & $\mathrm{H}$ & $(Z)-\mathbf{1 c}$ & Morpholine (2a) & EtOH, rt, $72 \mathrm{~h}$ & 3ca (85) \\
\hline 10 & $\mathrm{CN}$ & $\mathrm{CO}_{2} \mathrm{Et}$ & $\mathrm{H}$ & $(Z)-1 c$ & Morpholine (2a) & EtOH, rt, 16 kbar, 24 h & 3ca (91) \\
\hline 11 & $\mathrm{CN}$ & $\mathrm{CO}_{2} \mathrm{Et}$ & $\mathrm{H}$ & (Z)-1c & Benzylamine (2b) & EtOH, rt, 72 h & $\begin{array}{l}3 \operatorname{cb}(54)+ \\
4 \operatorname{cb}(32)^{c}\end{array}$ \\
\hline 12 & $\mathrm{CN}$ & $\mathrm{CO}_{2} \mathrm{Et}$ & $\mathrm{H}$ & (Z)-1c & Benzylamine (2b) & $\mathrm{EtOH}, \mathrm{rt}, 72 \mathrm{~h}+\mathrm{LiClO}_{4}$ & $\begin{array}{l}\text { 3cb }(28)+ \\
4 \mathbf{c b}(43)^{d}\end{array}$ \\
\hline 13 & $\mathrm{CN}$ & $\mathrm{CO}_{2} \mathrm{Et}$ & $\mathrm{H}$ & (Z)-1c & PhNHMe (2d) & $\mathrm{EtOH}, 120^{\circ} \mathrm{C}, 4 \mathrm{~h}$ & - \\
\hline 14 & $\mathrm{NO}_{2}$ & $\mathrm{CO}_{2} \mathrm{Et}$ & $\mathrm{H}$ & (E)-1d & Morpholine (2a) & DCM, rt, $1 \mathrm{~h}$ & $4 \mathbf{d a}(98)^{\mathrm{e}}$ \\
\hline 15 & $\mathrm{NO}_{2}$ & $\mathrm{CO}_{2} \mathrm{Et}$ & $\mathrm{H}$ & $(E)-\mathbf{1 d}$ & Benzylamine (2b) & $\mathrm{DCM}, 0^{\circ} \mathrm{C}, 1 \mathrm{~h}$ & $\mathbf{4 d b}(81)^{\mathrm{e}}$ \\
\hline 16 & $\mathrm{CN}$ & $\mathrm{CO}_{2} \mathrm{Me}$ & $\mathrm{Ph}$ & $(E)-\mathbf{1 e}$ & Morpholine (2a) & $\mathrm{THF}, 85^{\circ} \mathrm{C}, 7 \mathrm{~h}$ & 4ea $(85)^{f}$ \\
\hline 17 & $\mathrm{CN}$ & $\mathrm{CO}_{2} \mathrm{Me}$ & $\mathrm{Ph}$ & $(E)-\mathbf{1 e}$ & Benzylamine (2b) & THF, $85^{\circ} \mathrm{C}, 7 \mathrm{~h}$ & $4 e b(75)^{f}$ \\
\hline 18 & $\mathrm{CN}$ & $\mathrm{CO}_{2} \mathrm{Et}$ & $\mathrm{Me}$ & $(E)-\mathbf{1 f}$ & Morpholine (2a) & $\mathrm{EtOH}, 100^{\circ} \mathrm{C}, 5 \mathrm{~h}$ & $5(24)$ \\
\hline
\end{tabular}

${ }^{\mathrm{a}}$ Isolated yield.

${ }^{\mathrm{b}}$ Compound 3ac was obtained in pure state after decompression and solvent evaporation without further chromatographic purification.

${ }^{\mathrm{c}}$ The ration of $\mathbf{3} \mathbf{c b}: \mathbf{4} \mathbf{c b}$ is $61: 39$ (determined from crude ${ }^{1} \mathrm{H}$ NMR of the reaction mixture).

${ }^{\mathrm{d}}$ The ration of $\mathbf{3} \mathbf{c b}: \mathbf{4} \mathbf{c b}$ is $43: 57$ (determined from crude ${ }^{1} \mathrm{H}$ NMR of the reaction mixture).

${ }^{\mathrm{e}}$ Data taken from literature. ${ }^{[13]}$

${ }^{\mathrm{f}}$ The syn:anti diastereomeric ratio $(\mathrm{dr})$ is $\approx 55: 45$.

We next considered the case of methyl 4-oxopentenoate $(E)$-1b bearing two $\pi$-conjugated electron-withdrawing groups, namely a methoxycarbonyl and a carbonyl. This latter function is expected to exert a superior electron-withdrawing effect, and indeed, when $\mathbf{1 b}$ was reacted with 
benzylamine, the $\alpha$-amino ester $\mathbf{4 b a}$ was isolated, albeit in medium yield. If the addition of morpholine on the same enone proceeds with the same regioselectivity, the reaction is almost quantitative this time (Table 1, entries 6 and 8). Note that the yield is not as good when the reaction is run in methanol and under 16 kbar (entry 7) probably due to a competitive oxa-Michael addition of the alcohol. ${ }^{[24-28]}$ The proposed structure for $\mathbf{4 b a}$ was unambiguously confirmed by X-ray data (Fig. 1).

Figure 1. X-ray crystal structure of adduct $4 \mathbf{b a}$.

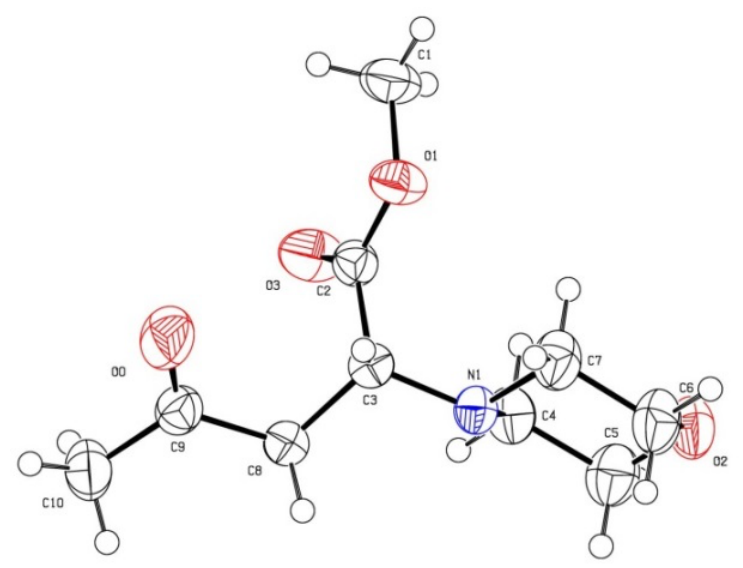

The following doubly depleted olefin we considered was ethyl cyanoacrylate $(Z)-1 \mathbf{c}$ in which the two conjugated electron-withdrawing groups compete in a subtle manner, one being $s p$ hybridized and the other $s p^{2}$. When we reacted enoate 1c with morpholine 2a, we recovered, selectively this time, the $\beta$-amino ester 3ca in high yields, in both classical and hyperbaric conditions (Table 1, entries 9 and 10). In contrast, this olefin reacts with benzylamine $\mathbf{2 b}$ leading to a mixture of regioisomers $\mathbf{3 c b}$ and $\mathbf{4 c b}$ in a 63:37 ratio (Table 1, entry 11). Careful analysis of 2D NMR spectra and 1D ${ }^{1} \mathrm{H}$-coupled ${ }^{13} \mathrm{C}$ NMR allowed us to determine unambiguously the structure of each regioisomer (See SI, S16-S19; S35-S41). If most organic chemist would undoubtedly consider a cyano group to be more electron-withdrawing than an ester and would 
therefore expect $\mathbf{4 c b}$ to be the predominant product, other parameters such as steric or proton acceptor characters are evidently to be considered in this competition. ${ }^{[29]}$

Indeed, the less sterically demanding cyano group in 1c drives the exclusive attack of morpholine at $\beta$-position. Moreover, the adduct 3ca is thermodynamically more stable than its isomer 4 ca by $4.12(\mathrm{PCM})$ or $4.31 \mathrm{kcal} / \mathrm{mol}$ (supermolecule with two molecules of ethanol), respectively. In contrast, the thermodynamic stability of isomeric adducts $\mathbf{3 c b}$ and $\mathbf{4 c b}$ are closer: amino ester $\mathbf{3 c b}$ is more stable than $\mathbf{4 c b}$ by $1.4 \mathrm{kcal} / \mathrm{mol}$ only, probably due to the stabilizing and leveling effects of hydrogen bonds.

The tangled steric and electronic variations associated to the passage from a primary to a secondary amine prevented us from simple deciphering these results. No reaction occurred when poorly nucleophilic amines (such as N-methylaniline) were used in the reaction even after a long reaction time (Table 1, entry 13).

As mentioned in the Introduction, the addition of nitrogen nucleophiles to acrylates bearing a vicinal nitro group was the object of previous works. In particular, the reaction of $\beta$-nitroacrylate E-1d with morpholine or benzylamine was previously described by Anderson and co-authors. ${ }^{[13]}$ As expected, enoate 1d, bearing one of the strongest electron-withdrawing groups, added both amines fast and in clear regioselectivity to give $\alpha$-amino ester in high yield (Table 1, entries 14, 15). The reaction was performed in dichloromethane to prevent the competitive addition of alcohol to the substrate.

Recently, Mayr et al. showed that rate constants for conjugate nucleophilic addition can be used to value the electrophilicities of Michael acceptors. Thus, the nucleophile-independent empirical electrophilicity parameters for simple monoacceptor-substituted olefins were determined. ${ }^{[30]}$ According to this research, the electron-acceptor ability of the functional groups (as a measure of electrophilicity of such substrates) follows the order $\mathrm{C}(\mathrm{O}) \mathrm{Me}>\mathrm{CO}_{2} \mathrm{Me}>\mathrm{CN} \geq$ $\mathrm{CO}_{2}$ Et. These results are in good agreement with our experimental data. For example, the electrophilicity parameters for cyano- and ethoxycarbonyl groups are very close (-19.05 and -19.07 
respectively), ${ }^{[30]}$ that is probably why both regioisomers are obtained with benzylamine (Table 1 , entry 11).

It is interesting to note that the solvent can alter the selectivity, as demonstrated by substituting protic solvents by aprotic ones in the reaction of cyanoacrylate 1c with benzylamine $\mathbf{2 b}$. Ester 3cb becomes indeed the sole reaction product when the reaction is performed in aprotic solvent (Table 2, entries 1-4).

Table 2. Dependence of ratio 3cb:4cb on the solvent

\begin{tabular}{llc}
\hline$\#$ & Solvent $^{\mathrm{a}}$ & $\begin{array}{c}\text { 3cb }: \mathbf{4 c b} \\
\text { isomer ratio }^{\mathrm{b}}\end{array}$ \\
\hline 1 & Benzene & $100: 0$ \\
2 & DMSO & $100: 0$ \\
3 & THF & $100: 0$ \\
4 & neat & $92: 8$ \\
5 & TFE & $67: 33$ \\
6 & EtOH & $63: 37$ \\
\hline
\end{tabular}

${ }^{\text {a }}$ Conditions: rt, $24 \mathrm{~h}$.

${ }^{\mathrm{b}}$ Estimated from ${ }^{1} \mathrm{H}$ NMR integrations.

The data in Table 2 show that parameter solely obtained on the basis of kinetic measurements do not always adequately describe the observed patterns of the direction of nucleophilic attacks. Therefore, this approach based on experimentally determined electrophilicity indices for aprotic solvents does not take into account the solvent influence which has, here, a significant effect on the regioselectivity of the nucleophilic addition.

\section{Theoretical considerations}

Since the above experimental results do not lead to a simple rule that effectively predicts the regioselectivity, we have performed a computational study designed to unravel the factors controlling the regioselectivity of the nucleophilic addition of amines. Since its introduction into chemistry, the analysis of the conceptual DFT indices has become a powerful tool in the hand of theoretical and synthetic chemists for analysis of chemical reactivity of organic compounds. ${ }^{[31]}$ 
As well known, the reactivity of most organic molecules can be regarded as nucleophilic electrophilic interactions. All estimates of the site of electrophilic or nucleophilic attack strongly depend on the theoretical approach. The Fukui indices provide, as a first approximation, a fair gauge to evaluate the electrophilic sites of the molecules we have considered, in line with previous results on structurally related electron deficient olefins. Another approach deals with the calculation of the local electrophilicity and nucleophilicity index which is known to be able to predict the best site for a nucleophilic or electrophilic attack. ${ }^{[32]}$ We tried to compare these approaches to theoretically explain the experimental selectivity of conjugate nucleophilic addition of amine to pull-pull alkenes.

To quantify the relative importance of the physicochemical parameters involved and better anticipate the reactivity of the studied substrates, first we carried out quantum-chemical calculations of the Fukui index for all Michael acceptors 1a-f, using the Multiwfn package. ${ }^{[33]}$

The Fukui functions for olefinic centers were calculated according to the formula (1): ${ }^{[34]}$

$$
f_{k}^{+}=q_{k}(N+1)-q_{k}(N)
$$

where $f_{k}{ }^{+}$is a Fukui index for atom $k, q_{k}(N+1)$ and $q_{k}(N)$ - Hirshfeld charges for the systems with $N+1$ and $N$ electrons, respectively.

The results show that the relative electrophilicity of the carbon directly connected to the trifluoromethyl group (for 1a) is slightly higher than that for the adjacent olefinic carbon (Table 3). In contrast, the double bond polarization in $\mathbf{1 b}$ and $\mathbf{1 d}$ is inverted by the acetyl group: in this case the carbon attached to the ester function becomes the most electrophilic centre of the molecule. Therefore, we have shown that, in general, Fukui parameters correlate well with the reactivity of such systems, but not always. ${ }^{[35]}$ Indeed, if Fukui indices predict correctly the site of the nucleophilic attack, ${ }^{[36,37]}$ they fail in some complex cases for which the local electrophilicity index $\omega_{\mathrm{k}}$, based on Hirshfeld charges, is generally preferred. ${ }^{[38,39]}$

Table 3. Fukui functions for di- and tri-substituted alkenes 1a-e calculated at the B3LYP/aug-cc-pVTZ level, $e^{-}$. 


\begin{tabular}{|c|c|c|c|c|c|c|}
\hline \multicolumn{7}{|c|}{ 1a-e } \\
\hline Entry & $\begin{array}{l}\text { Michael } \\
\text { acceptor }\end{array}$ & $\mathrm{EWG}^{1}$ & $\mathrm{EWG}^{2}$ & $\mathrm{R}$ & $\mathrm{C}_{\alpha}$ & $\mathrm{C}_{\beta}$ \\
\hline 1 & $(E) \mathbf{- 1 a}$ & $\mathrm{CF}_{3}$ & $\mathrm{CO}_{2} \mathrm{Et}$ & $\mathrm{H}$ & 0.06 & 0.09 \\
\hline 2 & $(E)-\mathbf{1 b}$ & Ac & $\mathrm{CO}_{2} \mathrm{Me}$ & $\mathrm{H}$ & 0.07 & 0.03 \\
\hline 3 & $(Z)-1 c$ & $\mathrm{CN}$ & $\mathrm{CO}_{2} \mathrm{Et}$ & $\mathrm{H}$ & 0.13 & 0.11 \\
\hline 4 & $(E)-\mathbf{1 d}$ & $\mathrm{NO}_{2}$ & $\mathrm{CO}_{2} \mathrm{Et}$ & $\mathrm{H}$ & 0.09 & 0.03 \\
\hline 5 & $(E)-\mathbf{1 e}$ & $\mathrm{CN}$ & $\mathrm{CO}_{2} \mathrm{Me}$ & $\mathrm{Ph}$ & 0.15 & 0.11 \\
\hline
\end{tabular}

In fact, the data in Table 3 show that the Fukui functions predict correctly the best sites for a nucleophilic attack. To confirm these results, we decided to compute the global and local electrophilicity indices. However, the limited range of variation of the calculated values (see SI, Tables S1, S2) was insufficient to predict the direction of the nucleophilic attack (low sensitivity). To improve the situation, we decided to estimate the local electrophilicity index as an inverse local nucleophilicity. A similar approach has been successfully used before to describe the reactivity of arenes and heteroarenes. ${ }^{[40]}$

We calculated, at the augmented triple-zeta level, 70 local electrophilicity indices for the $\alpha$ and $\beta$ centers of 5 substrates 1a-e in seven different models that account for the solvent effect. All 70 points showed a very good correlation with experiment (see Table 4 and Figures 2). It was shown that the sensitivity of the proposed parameter to the distribution of charges is significantly (more than 2 times) higher than that of the classical local electrophilicity index.

This parameter can be expressed as the inverse of the nucleophilicity value:

$$
\omega_{k}=\frac{1}{N_{k}}
$$

The parameter $\mathrm{N}_{\mathrm{k}}$ is itself defined by the equation:

$N_{k}=N_{N u} * f_{k}^{-}$,

where $f_{k}^{-}$is a Fukui index for atom $\mathrm{k}$, and $\mathrm{N}_{\mathrm{Nu}}$ is a global nucleophilicity index expressed as: 
$N_{N u}=E_{\text {Номо }}(N u)-E_{\text {Номо }}(T C E)$

where $\mathrm{Nu}$ represents the nucleophile, and TCE the tetracyanoethylene, whose HOMO energy is chosen as the reference value. ${ }^{[1]}$ The results of the theoretical study are presented in Table 4: the larger the absolute value, the less electrophilic the site is.

Table 4. Inverse local nucleophilicity indices of the alkenes 1a-e calculated at the B3LYP/augcc-pVTZ level, $e^{-} \cdot e V$.<smiles></smiles>

1a-e

\begin{tabular}{|c|c|c|c|c|c|c|c|c|}
\hline \multirow{2}{*}{ Alkene } & \multirow{2}{*}{$\begin{array}{l}\text { Atom } \\
\text { site }\end{array}$} & \multirow{2}{*}{$\begin{array}{c}\text { Gas } \\
\text { phase }\end{array}$} & \multirow{2}{*}{$\begin{array}{l}\text { DMSO } \\
(\mathrm{PCM})\end{array}$} & \multirow{2}{*}{$\begin{array}{c}\text { Benzene } \\
\text { (PCM) }\end{array}$} & \multirow{2}{*}{$\begin{array}{c}\text { Ethanol } \\
\text { (PCM) }\end{array}$} & \multicolumn{3}{|c|}{ Ethanol (Supermolecule) $^{\mathrm{a}}$} \\
\hline & & & & & & $\mathrm{EWG}^{1}$ & $\mathrm{EWG}^{2}$ & $\mathrm{EWG}^{1}+\mathrm{EWG}^{2}$ \\
\hline \multirow{2}{*}{$1 \mathbf{a}$} & $\alpha$ & 12.64 & 23.31 & 25.83 & 26.36 & 29.01 & 14.43 & 81.46 \\
\hline & $\beta$ & 8.84 & 17.02 & 16.04 & 19.21 & 21.96 & 10.66 & 48.50 \\
\hline \multirow{2}{*}{$1 \mathbf{b}$} & $\alpha$ & 7.30 & 8.01 & 7.75 & 8.54 & 17.47 & 11.24 & 25.13 \\
\hline & $\beta$ & 14.03 & 13.21 & 14.85 & 14.28 & 19.34 & 36.85 & 47.02 \\
\hline \multirow{2}{*}{ 1c } & $\alpha$ & 5.73 & 5.84 & 11.06 & 6.48 & 14.45 & 10.78 & 28.31 \\
\hline & $\beta$ & 6.72 & 6.54 & 10.68 & 7.27 & 19.31 & 10.039 & 47.89 \\
\hline \multirow{2}{*}{ 1d } & $\alpha$ & 5.77 & 5.83 & 5.71 & 5.82 & 7.75 & 7.29 & 10.19 \\
\hline & $\beta$ & 16.41 & 13.85 & 15.12 & 13.93 & 31.72 & 22.35 & 48.54 \\
\hline \multirow{2}{*}{$1 \mathrm{e}$} & $\alpha$ & 4.86 & 5.14 & 7.02 & 5.17 & 6.49 & 7.07 & 40.32 \\
\hline & $\beta$ & 13.56 & 6.98 & 9.34 & 7.04 & 11.35 & 10.60 & 83.17 \\
\hline
\end{tabular}

a Optimization of geometric parameters and calculation of the inverse local nucleophilicity indices for intermolecular substrate-solvent complexes, in which the coordination of the proton of the ethanol hydroxyl group was realized on $\mathrm{EWG}^{1}, \mathrm{EWG}^{2}$, and both $\mathrm{EWG}^{1}$ and $\mathrm{EWG}^{2}$, correspondingly.

These data show that the preferred site for the nucleophilic attack on enoate $1 \mathbf{a}$ is the $\beta$ olefinic carbon: the inverse local nucleophilicity index value computed for the $\beta$-atom is $>1,4$ times lower than that for the $\alpha$-atom. In contrast, the $\alpha$-olefinic carbon of enoates $\mathbf{1 b}$-e is the most electrophilic centre of the molecule. The electron-withdrawing properties of both substituents determine a bond polarity and, as a consequence, the regioselectivity. Note that only for enoate 1c the inverse local nucleophilicity indices of olefinic carbons are similar. These results suggest that the smallest changes in the reaction conditions could lead to changes in the direction of the nucleophilic attack. 
For acrylates 1a-d the inverse local nucleophilicity index of olefin atoms were calculated in the gas phase (column 3). Solvent effects were simulated using a Tomasi IEF-PCM polarizable continuum model ${ }^{[39]}$ for aprotic (DMSO or benzene, column 4 and 5) or protic solvents (ethanol, column 6) with the coordination at $\mathrm{EWG}^{1}$ (column 7) or $\mathrm{EWG}^{2}$ (column 8) or at both functions (column 9).

These results show that, in almost all cases, the inverse local nucleophilicity index value increases with respect to those obtained in absence of a continuum model. Therefore, the implicit consideration of the medium polarity does not account for the solvent effect.

We thus decided to switch to supermolecules in which the solvent(s) are explicitly incorporated. Actually, ethanol interacts with both EWGs of substrates 1, increasing their electronwithdrawing properties. In all cases, a stable supramolecular complex is obtained with two solvent molecules, no more. Therefore, the experimental results were best described when both the explicit solvent molecules and the polarization IEF-PCM model were applied together.

The calculated inverse local nucleophilicity indices for 1a-e (Table 4) were used to plot the dependence of these indices on the solvation models. We showed that the direction of the preferable nucleophilic attack is the same for each model involving solvation effects (Figure 2).

Figure 2. The dependence of the inverse local nucleophilicity index calculated for alkenes 1c and 1d on the type of solvation model. 


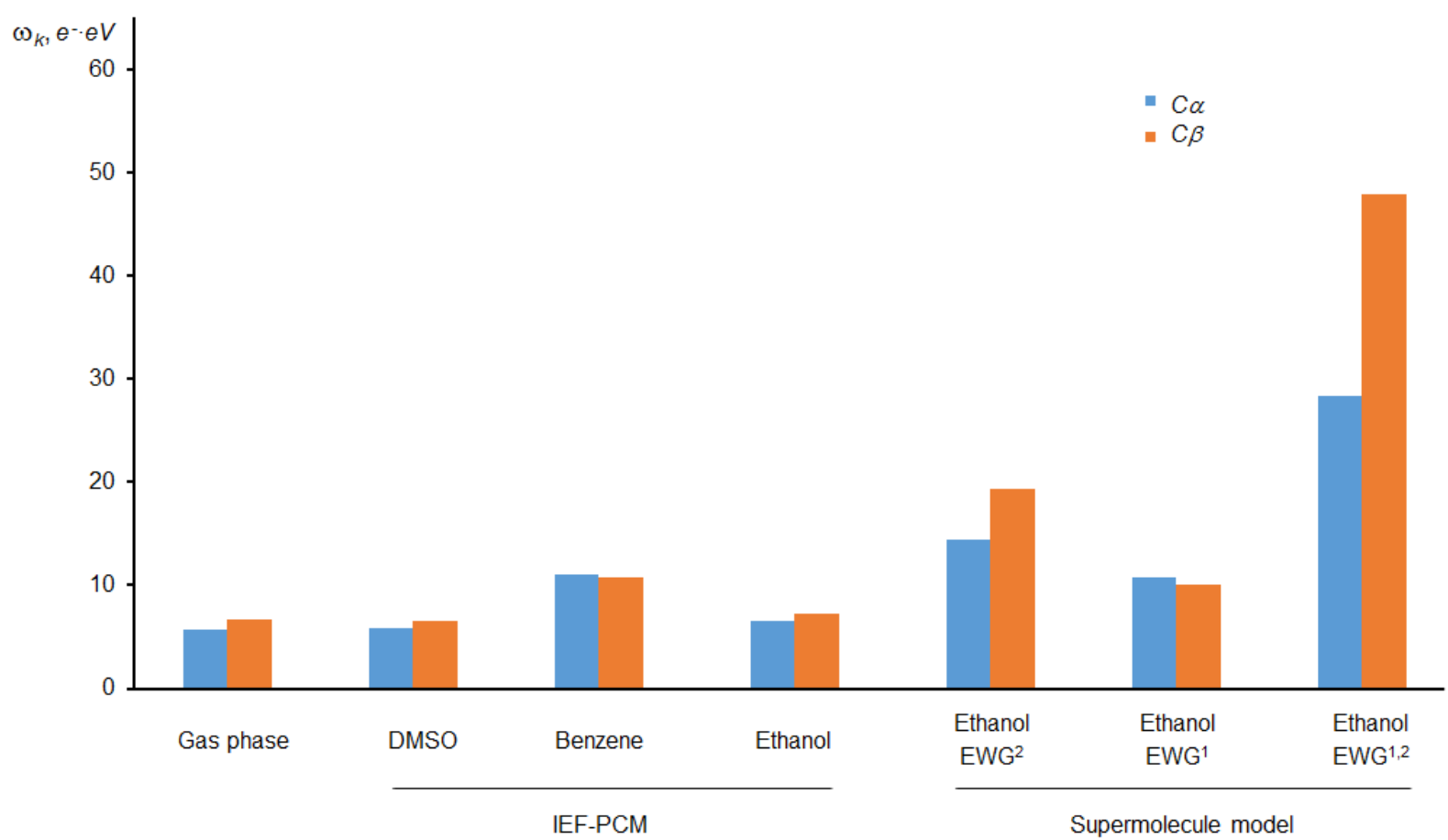

$1 d$

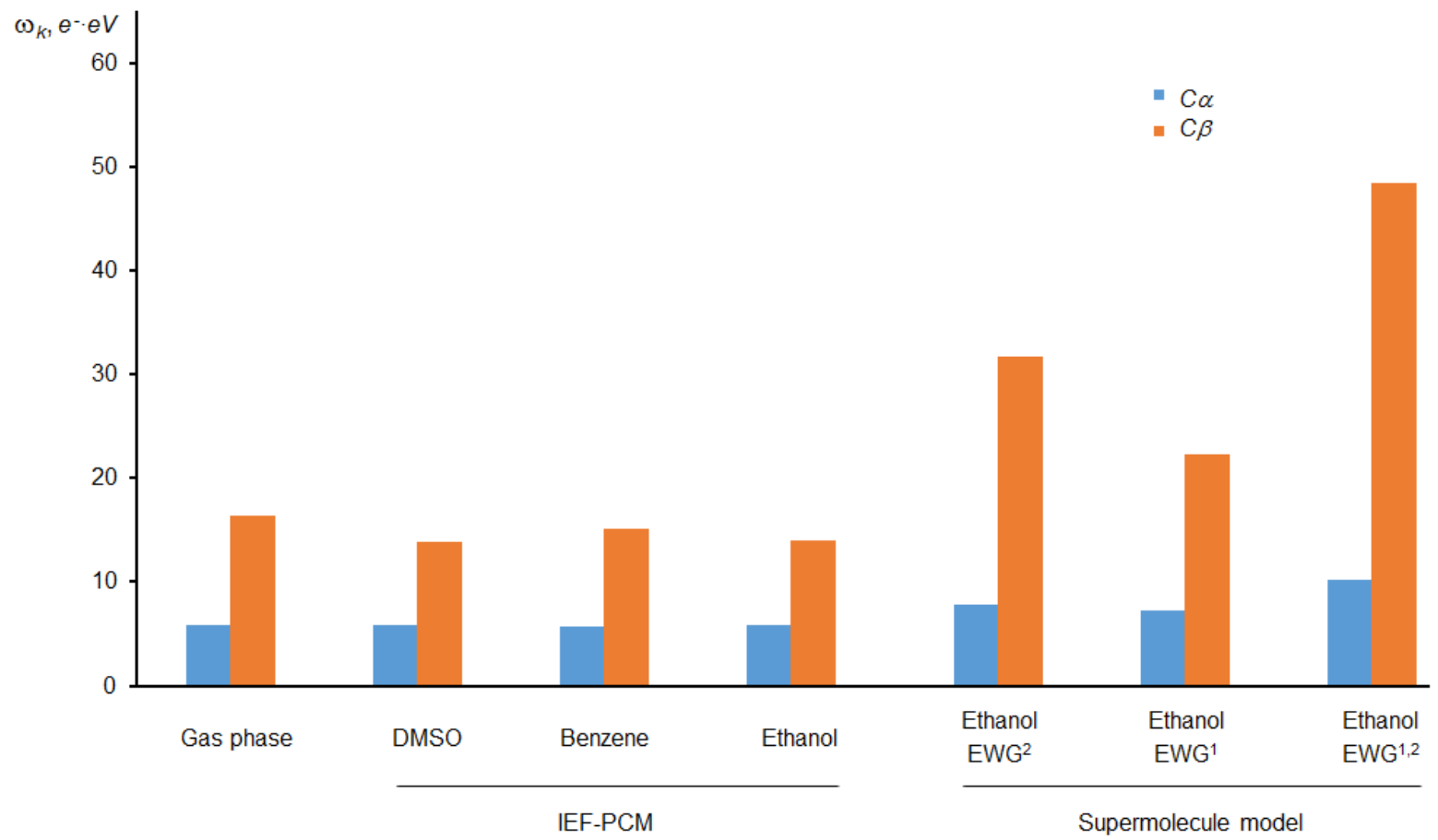

It is very interesting to note that the calculations of the inverse local nucleophilicity index for alkene 1c bearing cyano- and alkoxycarbonyl groups allows to conclude that the nucleophilic attack is equal on the both olefinic carbons. Only in boundary cases there is a shift towards the $\alpha$ attack. This result is in excellent agreement with experimental data (Table 1, entry 12). Similar graphs for alkenes 1a,b,e are given in SI (S52- S54). Their analysis lead to conclusion that in all 
cases the function $\omega_{\mathrm{k}}$ tends to converge to its limit with an increase in the number of solvated molecules, taken into account explicitly. This is a strong evidence of the "performance" of the proposed model and the possibility of its application in such calculations.

Another obvious factor influencing the regioisomers ratio is the selective activation or deactivation of one of the functional groups. We thought that the interaction of $\mathbf{1}$ with a cation exhibiting strong Lewis acid properties could lead to chelation complexes in which the olefin would see its electron acceptor density map altered. To confirm this hypothesis, we added lithium perchlorate (100 mol\%) to the enoate 1c before reacting with benzylamine (Scheme 3$)$. It is well known that the lithium ion coordinates efficiently to the carbonyl oxygen. ${ }^{[43]}$ This complexation seems to decrease the $\pi$, $\pi$-conjugation between the ethoxycarbonyl group and the carbon-carbon double bond. Nevertheless, this phenomenon is one among several factors and it remains difficult to predict which regioisomer will benefit from the potential chelation.

Scheme 3. Lithium-mediated catalysis of nucleophilic addition

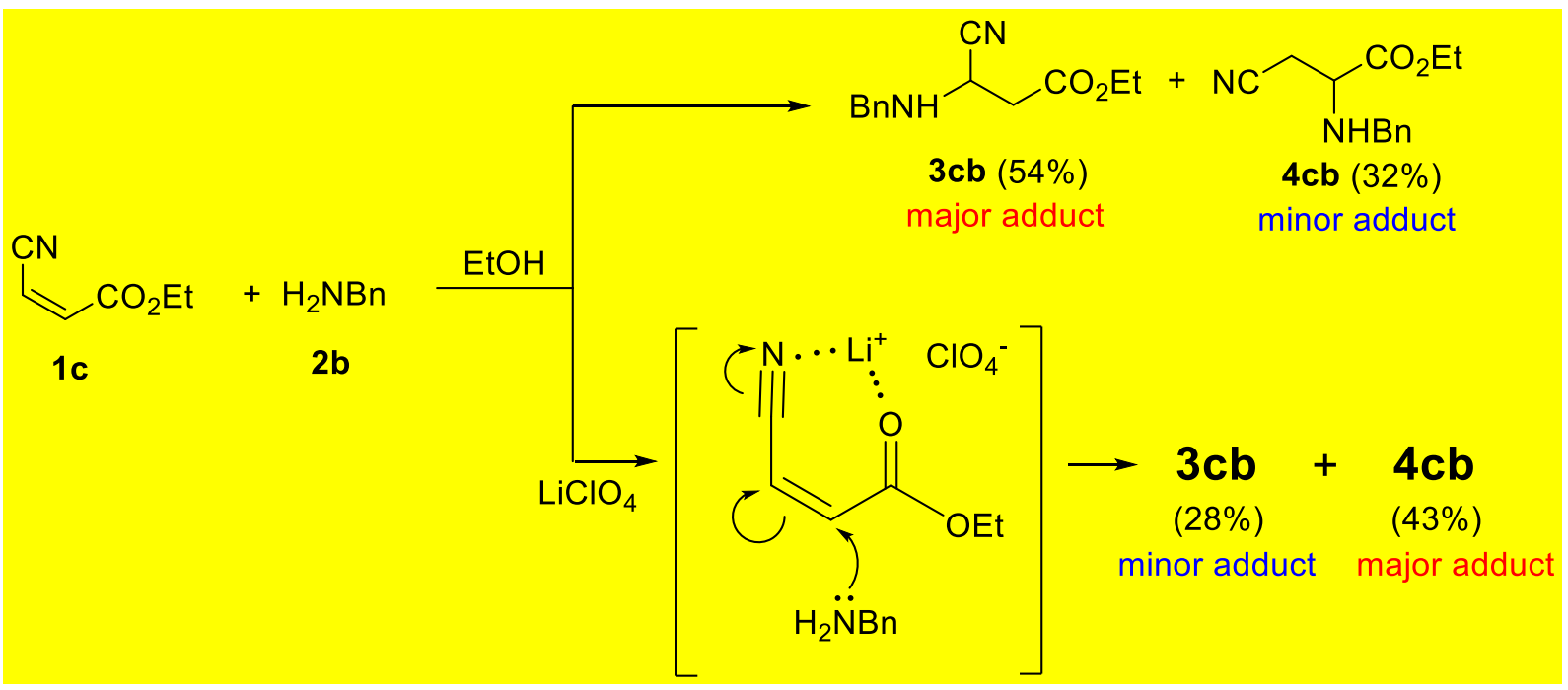

This is why the study was completed with a theoretical assessment of the possible lithium cation effect in interaction with the enoate 1c. The results show that the unsolvated $\mathrm{Li}^{+}$ends up chelated by the carbonyl oxygen and the nitrogen atom of the cyano group (Fig. 3). Topological analysis (AIM) of the electron density gives two bond critical points $(3,-1)$ type. This 
corresponds to non-covalent interaction of lithium cation with both carbonyl oxygen and cyano nitrogen.

Figure 3. AIM analysis of the optimized 1c-Li ${ }^{+}$complex (MP2/aug-cc-pVTZ). Interatomic distances are given in $\AA$. Green dots correspond to the bond critical points $(3,-1)$.

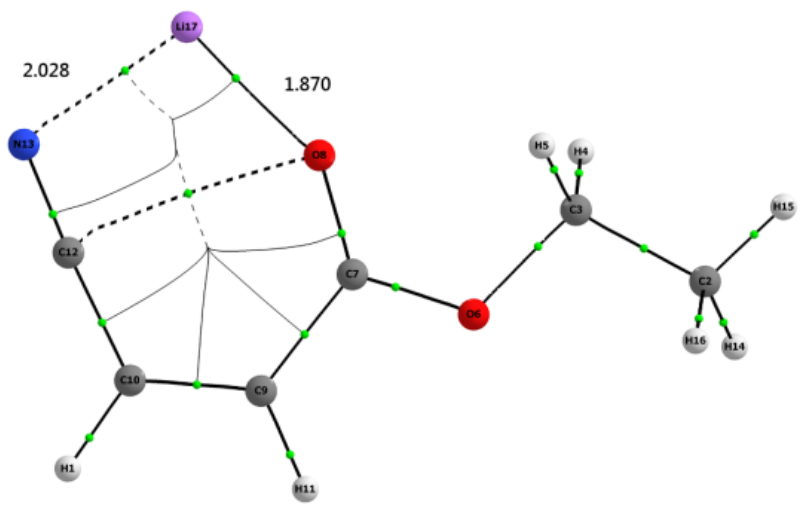

The obvious steric influence exerted by the double bond substituents was next evaluated extending the reaction to the trisubstituted Michael acceptors 1e,f. We observed that if one of the olefinic hydrogens is replaced by a phenyl (1e), the addition proceeds selectively to give the expected $\alpha$-amino esters $\mathbf{4 e a}$ or $\mathbf{4 e b}$ in high yield as the sole reaction product (Table 1 , entries 16 and 17). Their structure was easily determined by NMR spectroscopy and confirmed by X-ray data for 4ea (Fig. 4). It is worth mentioning that the inverse local nucleophilicity index computed for the $\beta$-olefinic carbon of enoate $1 \mathrm{e}$ is larger than that for its $\alpha$-centre (Table 4 ), in excellent agreement with experimental data.

Figure 4. X-ray crystal structure of adduct 4ea.

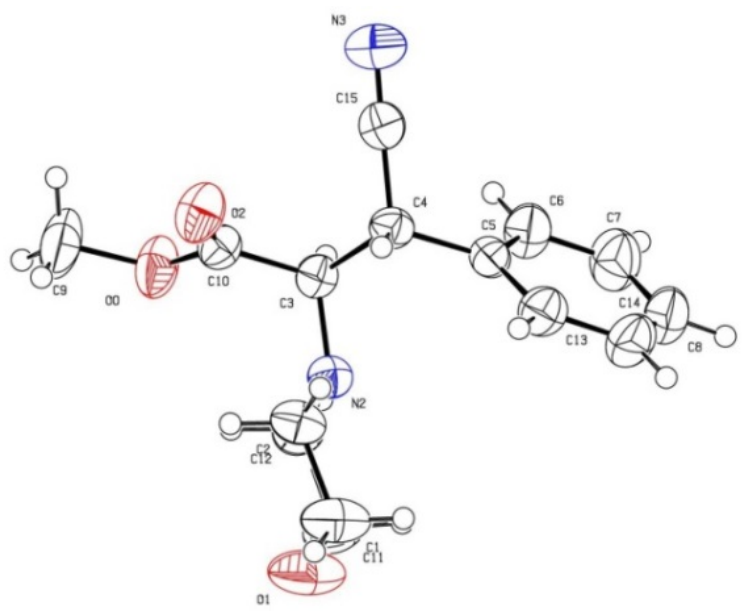


It should be noted that the effect of a phenyl substituent is highly dependent on its conformation. Notably, the probability of nucleophilic attack on one of the electrophilic centres of the acrylate 1e depends strongly on the conjugation between the double bond and the phenyl moiety. Rising the dihedral angle $\varphi$ leads to the simultaneous increase of the electrophilicity of the $\alpha$-olefinic carbon atom (See, SI, Figure 3).

In contrast, when 3-cyanobut-2-enoate 1f was treated with an equimolar amount of morpholine, the corresponding $\gamma$-morpholino ester 5 was isolated in moderate yield (Scheme 4). If the $\beta$-olefinic carbon of $\mathbf{1 f}$ is probably more accessible than that of $\mathbf{1 e}$, the electronic properties of a methyl group do not favour the addition into the $\alpha$-position. We suggest that the first step of the reaction is a prototropic transformation of the initial $\alpha, \beta$-enoate into its $\beta, \gamma$-isomer 6 . In such a case, a nucleophilic addition to the electron-deficient alkene bearing a terminal double bond could afford the final adduct 5 .

Scheme 4. Addition of morpholine to ethyl 3-cyanobut-2-enoate 1e.

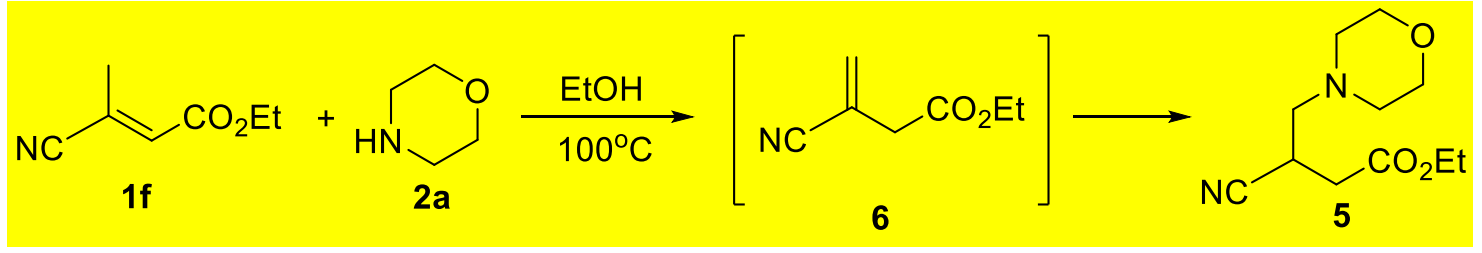

In conclusion, Michael acceptors 1a-d bearing two vicinal electron-withdrawing groups behave as electron-deficient olefins which react with nitrogen nucleophiles under mild conditions (catalyst free, in most cases at room temperature and under atmospheric pressure). Our results show that several parameters such as the substitution pattern of the olefin, the nature of the solvent, or the presence of chelating cations $\left(\mathrm{Li}^{+}\right)$are likely to alter significantly the regioselectivity of the addition. In spite of this complex dependence, the preferable direction of the conjugate nucleophilic addition of amines to unsymmetrical alkenes bearing two vicinal EWG groups can be predicted on computational bases. We show in this paper that the Fukui functions and local electrophilicity indices give good account on the reactivity of the competitive electrophilic sites. 
But the best agreement was reached with inverse local nucleophilicity indices. If these data obviously need to be further buttressed by a set of complementary experiments, they already demonstrate that this simple chemistry opens a selective access to functionalized $\alpha$ - or $\beta$ aminoesters from commercially available starting materials.

\section{Experimental Section}

General Remarks. ${ }^{1} \mathrm{H}(400.1 \mathrm{MHz}),{ }^{13} \mathrm{C}(100.6 \mathrm{MHz}){ }^{19} \mathrm{~F}(376.5 \mathrm{MHz})$, and ${ }^{15} \mathrm{~N}(40.6 \mathrm{MHz})$ NMR spectra were recorded on Bruker AVANCE $400 \mathrm{MHz}$ spectrometer. Chemical shifts $(\delta)$ are given in ppm; the coupling constants $(J)$ are given in Hertz. The concerted application of ${ }^{1} \mathrm{H}-{ }^{1} \mathrm{H}$ 2D homonuclear experiments NOESY and COSY as well as ${ }^{1} \mathrm{H}-{ }^{13} \mathrm{C} 2 \mathrm{D}$ heteronuclear experiments HMBC and HSQC were used for the distinction of the carbon and proton resonances. The IR spectra were recorded with a Bruker Vertex 70 FT-IR spectrometer and with a portable Varian 3100 diamond ATR/FT-IR spectrometer. The GC/MS analyses were performed with a Shimadzu GCMS-QP5050A instrument (EI, $70 \mathrm{eV})$. Agilent 6210 facility was used for HRMS-ESI spectra recording. The silica gel used for column chromatography was 230-400 Mesh. High pressure reactions were performed in a piston-cylinder type apparatus, designed for pressures up to $20 \mathrm{kbar}$. All reagents were of reagent grade and were used as such or distilled prior to use. All the solvents were dried according to standard procedures and freshly distilled prior to use.

\section{Computational details}

Geometry optimization of 1a-e was performed with GAUSSIAN 09 code ${ }^{[44]}$ at the B3LYP/ccpVTZ level. ${ }^{[45-47]}$ Cartesian coordinates of the resulting structures are given in the Supporting Information. All calculated structures are minima on the potential energy surfaces as proved by the absence of imaginary frequencies.

\section{General procedure for the synthesis of esters 3 and 4.}


A mixture of appropriate enoate $1(1 \mathrm{mmol})$ and amine $2(1 \mathrm{mmol})$ in ethanol $(2 \mathrm{~mL})$ was maintained at room temperature for $48-72 \mathrm{~h}$ or heated in a sealed tube to $85^{\circ} \mathrm{C}$ for $7 \mathrm{~h}$. The solvent was evaporated in vacuo. The crude product was purified by column chromatography (silica gel, eluent ether/hexane) to give target esters 3 or/and 4 . The following compounds were obtained by this procedure.

\section{Ethyl 4,4,4-trifluoro-3-(morpholino)butanoate 3aa}

Pale yellow oil, $179 \mathrm{mg}, 70 \%$ yield; ${ }^{1} \mathrm{H}$ NMR $\left(\mathrm{CDCl}_{3}\right): \delta 1.25\left(\mathrm{t}, J=7.2 \mathrm{~Hz}, 3 \mathrm{H}, \mathrm{CH}_{3}\right), 2.50-2.70$ (m, 4H, $\left.\mathrm{CH}_{2}, \mathrm{~N}\left(\mathrm{CH}_{2}\right)_{2}\right), 2.80-2.90\left(\mathrm{~m}, 2 \mathrm{H}, \mathrm{N}\left(\mathrm{CH}_{2}\right)_{2}\right), 3.55-3.65\left(\mathrm{~m}, 5 \mathrm{H}, \mathrm{CH}, \mathrm{O}\left(\mathrm{CH}_{2}\right)_{2}\right), 4.16(\mathrm{q}, J$

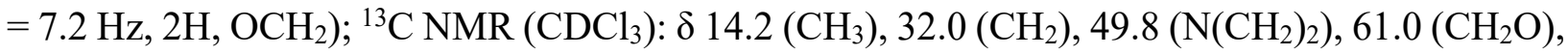
$62.6\left(\mathrm{q},{ }^{2} J_{\mathrm{CF}}=26.4 \mathrm{~Hz}, \mathrm{CH}\right), 67.6\left(\mathrm{O}\left(\mathrm{CH}_{2}\right)_{2}\right), 126.5\left(\mathrm{q},{ }^{1} \mathrm{~J}=290 \mathrm{~Hz}, \mathrm{CF}_{3}\right), 170.0(\mathrm{C}=\mathrm{O}) ;{ }^{15} \mathrm{~N} \mathrm{NMR}$ $\left(\mathrm{CDCl}_{3}\right):-344.4$ ppm. IR $\left(\mathrm{cm}^{-1}\right): v 1116,1157(\mathrm{C}-\mathrm{F}), 1741(\mathrm{C}=\mathrm{O}) . \mathrm{MS}(\mathrm{EI}), \mathrm{m} / \mathrm{z}(\%): 255$ [M ${ }^{+}$, 11], 212 (31), 186 (72), 168 (100), 124 (45), 86 (46). Calculated for $\mathrm{C}_{10} \mathrm{H}_{16} \mathrm{~F}_{3} \mathrm{NO}_{3}$ : C 47.06; $\mathrm{H}$ 6.32; N 5.49. Found: C 47.20; H 6.25; N 5.48.

\section{Ethyl 4,4,4-trifluoro-3-(benzylamino)butanoate 3ab}

Oil, 247 mg, 90\% yield; ${ }^{1} \mathrm{H}$ NMR $\left(\mathrm{CDCl}_{3}\right): \delta 1.24$ (t, $\left.J=7.2 \mathrm{~Hz}, 3 \mathrm{H}, \mathrm{CH}_{3}\right), 1.63$ (br.s., $\left.1 \mathrm{H}, \mathrm{NH}\right)$; $2.48\left(\mathrm{dd}, J=15.5,9.6 \mathrm{~Hz}, 1 \mathrm{H}, \mathrm{CH}_{2}\right), 2.68\left(\mathrm{dd}, J=15.5,4.0 \mathrm{~Hz}, 1 \mathrm{H}, \mathrm{CH}_{2}\right), 3.63-3.73(\mathrm{~m}, 1 \mathrm{H}$, $\mathrm{CHN}), 3.86\left(\mathrm{~d}, J=13.0 \mathrm{~Hz}, 1 \mathrm{H}, \mathrm{NCH}_{2}\right), 4.00\left(\mathrm{~d}, J=13.0 \mathrm{~Hz}, 1 \mathrm{H}, \mathrm{NCH}_{2}\right), 4.10-4.25(\mathrm{~m}, 2 \mathrm{H}$, $\left.\mathrm{OCH}_{2}\right), 7.25-7.35(\mathrm{~m}, 5 \mathrm{H}, \mathrm{Ph}) ;{ }^{13} \mathrm{C} \mathrm{NMR}\left(\mathrm{CDCl}_{3}\right): \delta 14.1\left(\mathrm{CH}_{3}\right), 35.1,52.1\left(\mathrm{CH}_{2} \mathrm{~N}\right), 56.4\left(\mathrm{q},{ }^{2} J_{\mathrm{CF}}\right.$ $=28 \mathrm{~Hz}, \mathrm{CH}), 61.1\left(\mathrm{OCH}_{2}\right), 126.5\left(\mathrm{q}, J=284 \mathrm{~Hz}, \mathrm{CF}_{3}\right), 127.4,128.3,128.5,139.6(\mathrm{Ph}), 169.5$ $(\mathrm{C}=\mathrm{O}) ;{ }^{19} \mathrm{~F} \mathrm{NMR}\left(\mathrm{CDCl}_{3}\right):-74.62(\mathrm{~d}, J=7.2 \mathrm{~Hz}) \mathrm{ppm}$. IR $\left(\mathrm{cm}^{-1}\right): v 1125(\mathrm{C}-\mathrm{F}), 1738(\mathrm{C}=\mathrm{O}), 3356$

(N-H). MS (EI), m/z (\%): $275\left[\mathrm{M}^{+},<1\right], 188(16), 106(97), 91$ (100). Calculated for $\mathrm{C}_{13} \mathrm{H}_{16} \mathrm{~F}_{3} \mathrm{NO}_{2}$ : C 56.72; H 5.86; N 5.09. Found: C 56.74; H 6.13; N 5.12.

Ethyl 4,4,4-trifluoro-3-(N-benzyl-N-(2-methylbenzyl)amino)butanoate 3ac 
Oil, $538 \mathrm{mg}, 95 \%$ yield; ${ }^{1} \mathrm{H} \mathrm{NMR}\left(\mathrm{CDCl}_{3}\right): \delta 1.25\left(\mathrm{t}, J=7.1 \mathrm{~Hz}, 3 \mathrm{H}, \mathrm{CH}_{3}\right), 1.42(\mathrm{~d}, J=6.0 \mathrm{~Hz}$, $\left.3 \mathrm{H}, \mathrm{CHCH}_{3}\right), 2.67-2.71\left(\mathrm{~m}, 2 \mathrm{H}, \mathrm{CH}_{2}\right), 3.63-3.73(\mathrm{~m}, 1 \mathrm{H}, \mathrm{CHN}), 3.84-3.86\left(\mathrm{~m}, 1 \mathrm{H}, \mathrm{CHCH}_{3}\right), 3.87-$ $3.97\left(\mathrm{~m}, 2 \mathrm{H}, \mathrm{OCH}_{2}\right), 4.20-4.28\left(\mathrm{~m}, 2 \mathrm{H}, \mathrm{NCH}_{2}\right), 7.25-7.45(\mathrm{~m}, 10 \mathrm{H}, \mathrm{Ph}) ;{ }^{13} \mathrm{C} \mathrm{NMR}\left(\mathrm{CDCl}_{3}\right): \delta 14.3$ $\left(\mathrm{CH}_{3}\right), 24.5\left(\mathrm{CHCH}_{3}\right), 35.3\left(\mathrm{q},{ }^{2} J_{\mathrm{CF}}=1.7 \mathrm{~Hz}, \mathrm{CH}_{2} \mathrm{CO}\right), 51.7\left(\mathrm{CH}_{2} \mathrm{~N}\right), 57.6\left(\underline{\mathrm{CHCH}_{3}}\right), 61.3\left(\mathrm{OCH}_{2}\right)$, $74.7\left(\mathrm{q},{ }^{2} J_{\mathrm{CF}}=32 \mathrm{~Hz}, \mathrm{NCHCF}_{3}\right), 125.5\left(\mathrm{q}, J=284 \mathrm{~Hz}, \mathrm{CF}_{3}\right), 126.9,127.0,127.1,128.3,128.5$, 128.6, 140.5, $145.5(\mathrm{Ph}), 169.8(\mathrm{C}=\mathrm{O}) \mathrm{ppm} . \mathrm{IR}\left(\mathrm{cm}^{-1}\right): v 1129(\mathrm{C}-\mathrm{F}), 1738(\mathrm{C}=\mathrm{O}) . \mathrm{MS}(\mathrm{EI}), \mathrm{m} / \mathrm{z}$ (\%): $379\left[\mathrm{M}^{+},<1\right], 364$ (8), 274 (11), 196 (34), 91 (100). Calculated for $\mathrm{C}_{21} \mathrm{H}_{24} \mathrm{~F}_{3} \mathrm{NO}_{2}$ : C 66.48; $\mathrm{H}$ 6.38; N 3.69. Found: C 66.69; H 6.55; N 3.64.

\section{Methyl 2-(morpholin-4-yl)-3-oxopentanoate 4ba}

Colourless needle crystals, $211 \mathrm{mg}, 98 \%$ yield; mp 66 ${ }^{\circ} \mathrm{C} ;{ }^{1} \mathrm{H} \mathrm{NMR}\left(\mathrm{CDCl}_{3}\right): \delta 2.16\left(\mathrm{~s}, 3 \mathrm{H}, \mathrm{CCH}_{3}\right)$, 2.35-2.50 (m, 2H, N(CH$\left.)_{2}\right), 2.55-2.70\left(\mathrm{~m}, 3 \mathrm{H}, \mathrm{CH}_{2}, \mathrm{~N}\left(\mathrm{CH}_{2}\right)_{2}\right), 3.02(\mathrm{dd}, J=17.1,9.2 \mathrm{~Hz}, 1 \mathrm{H}$, $\left.\mathrm{CH}_{2}\right)$, 3.55-3.65 (m, 4H, O( $\left.\left.\mathrm{CH}_{2}\right)_{2}\right), 3.71\left(\mathrm{~s}, 4 \mathrm{H}, \mathrm{CH}, \mathrm{OCH}_{3}\right) ;{ }^{13} \mathrm{C} \mathrm{NMR}\left(\mathrm{CDCl}_{3}\right): 30.3\left(\underline{\mathrm{CH}}_{3} \mathrm{CO}\right)$, $42.9\left(\mathrm{CH}_{2}\right), 50.3\left(\mathrm{~N}\left(\mathrm{CH}_{2}\right)_{2}\right), 51.6\left(\mathrm{OCH}_{3}\right), 63.1(\mathrm{CH}), 67.4\left(\mathrm{O}\left(\mathrm{CH}_{2}\right)_{2}\right), 171.3\left(\underline{\mathrm{CO}}_{2} \mathrm{Me}\right), 206.2$ $\left(\mathrm{CH}_{3} \underline{\mathrm{CO}}\right) ;{ }^{15} \mathrm{~N} \mathrm{NMR}\left(\mathrm{CDCl}_{3}\right):-335.9$ ppm. IR $\left(\mathrm{cm}^{-1}\right): v 1115,1163(\mathrm{C}-\mathrm{O}-\mathrm{C}), 1724(\mathrm{C}=\mathrm{O}) . \mathrm{MS}$ (EI), m/z (\%): 215 [M+ $\left.\mathrm{M}^{+}, 2\right], 156$ (100), 114 (93) 43 (51). Calculated for $\mathrm{C}_{9} \mathrm{H}_{15} \mathrm{NO}_{4}$ : C 55.80; $\mathrm{H}$ 7.96; N 6.51. Found: C 55.67; H 7.77; N 6.32.

\section{Methyl 2-(benzylamino)-4-oxopentanoate 4bb}

Colourless oil, $135 \mathrm{mg}, 57 \%$ yield; ${ }^{1} \mathrm{H}$ NMR $\left(\mathrm{CDCl}_{3}\right)$ : 2.01 (s, $\left.1 \mathrm{H}, \mathrm{NH}\right), 2.09$ (s, 3H, $\left.\mathrm{CH}_{3} \mathrm{CO}\right)$, $2.65-2.90\left(\mathrm{~m}, 2 \mathrm{H}, \mathrm{CH}_{2} \mathrm{CO}\right), 3.57-3.75\left(\mathrm{~m}, 5 \mathrm{H}, \mathrm{OCH}_{3}, \mathrm{CH}, \mathrm{NCH}_{2}\right), 3.83(\mathrm{~d}, J=13.0 \mathrm{~Hz}, 1 \mathrm{H}$, $\left.\mathrm{NCH}_{2}\right), 7.13-7.34(\mathrm{~m}, 5 \mathrm{H}, \mathrm{Ph}) ;{ }^{13} \mathrm{C} \mathrm{NMR}\left(\mathrm{CDCl}_{3}\right): 30.1\left(\mathrm{CH}_{3} \mathrm{CO}\right), 46.6\left(\mathrm{CH}_{2}\right), 52.0\left(\mathrm{OCH}_{3}\right)$, $52.1\left(\mathrm{CH}_{2} \mathrm{~N}\right), 56.4(\mathrm{CH}), 127.1,128.2,128.3,139.6(\mathrm{Ph}), 174.4\left(\underline{\mathrm{CO}}_{2} \mathrm{Me}\right), 205.9\left(\mathrm{CH}_{3} \underline{\mathrm{CO}}\right) ;{ }^{15} \mathrm{~N}$ NMR $\left(\mathrm{CDCl}_{3}\right):-336.0$ ppm. IR $\left(\mathrm{cm}^{-1}\right): v 1730(\mathrm{C}=\mathrm{O}), 3333(\mathrm{NH}) . \mathrm{MS}(\mathrm{EI}), \mathrm{m} / \mathrm{z}(\%): 235$ [M $\left.\mathrm{M}^{+},<1\right]$, 177 (34), 176 (51), 144 (41), 134 (36), 117 (27), 106 (41), 91 (100), 65 (37), 43 (37). Calculated for $\mathrm{C}_{13} \mathrm{H}_{17} \mathrm{NO}_{3}$ : C 66.36; H 7.28; N 5.95. Found: C 66.48; H 7.10; N 5.95. 


\section{Ethyl 3-cyano-3-(morpholin-4-yl)propanoate 3ca}

Pale yellow oil, $181 \mathrm{mg}, 85 \%$ yield; ${ }^{1} \mathrm{H} \mathrm{NMR}\left(\mathrm{CDCl}_{3}\right): \delta 1.22\left(\mathrm{t}, J=7.1 \mathrm{~Hz}, 3 \mathrm{H}, \mathrm{CH}_{3}\right), 2.47(\mathrm{~m}$, $\left.2 \mathrm{H}, \mathrm{N}\left(\mathrm{CH}_{2}\right)_{2}\right), 2.62\left(\mathrm{~m}, 2 \mathrm{H}, \mathrm{N}\left(\mathrm{CH}_{2}\right)_{2}\right), 2.65-2.79\left(\mathrm{~m}, 2 \mathrm{H}, \mathrm{CH}_{2}\right), 3.65\left(\mathrm{~m}, 4 \mathrm{H}, \mathrm{O}\left(\mathrm{CH}_{2}\right)_{2}\right), 3.97$ (t, $J=7.7 \mathrm{~Hz}, 1 \mathrm{H}, \mathrm{CH}), 4.14\left(\mathrm{q}, J=7.1 \mathrm{~Hz}, 2 \mathrm{H}, \mathrm{OCH}_{2}\right) ;{ }^{13} \mathrm{C} \mathrm{NMR}\left(\mathrm{CDCl}_{3}\right): \delta 14.1\left(\mathrm{CH}_{3}\right), 35.9\left(\mathrm{CH}_{2}\right)$, $49.4\left(\mathrm{~N}\left(\mathrm{CH}_{2}\right)_{2}\right), 54.0(\mathrm{CH}), 61.3\left(\mathrm{CH}_{2} \mathrm{O}\right), 66.4\left(\mathrm{O}\left(\mathrm{CH}_{2}\right)_{2}\right), 115.5(\mathrm{C} \equiv \mathrm{N}), 168.7(\mathrm{C}=\mathrm{O}) ;{ }^{15} \mathrm{~N}$ NMR $\left(\mathrm{CDCl}_{3}\right)$ : -337.5 $\left(\mathrm{N}\left(\mathrm{CH}_{2}\right)_{2}\right),-125.5(\mathrm{CN}) \mathrm{ppm}$. IR $\left(\mathrm{cm}^{-1}\right): v 1119,1195,2230(\mathrm{C} \equiv \mathrm{N}), 1737(\mathrm{C}=\mathrm{O})$. MS (EI), m/z (\%): 212 [M+, 21], 156 (21), 126 (23), 125 (100), 112 (30), 109 (52), 86 (73), 54 (77), 42 (43). Calculated for $\mathrm{C}_{10} \mathrm{H}_{16} \mathrm{~N}_{2} \mathrm{O}_{3}$ : C 56.59; H 7.60; N 13.20. Found: C 56.75; H 7.60; N 12.98 .

\section{Ethyl 3-(benzylamino)-3-cyanopropanoate 3cb}

Colourless oil, $125 \mathrm{mg}, 54 \%$ yield; ${ }^{1} \mathrm{H} \mathrm{NMR}\left(\mathrm{CDCl}_{3}\right): \delta 1.26\left(\mathrm{t}, J=7.2 \mathrm{~Hz}, 3 \mathrm{H}, \mathrm{CH}_{3}\right), 2.11(\mathrm{~s}, 1 \mathrm{H}$, $\mathrm{NH}), 2.67-2.84\left(\mathrm{~m}, 2 \mathrm{H}, \mathrm{CCH}_{2}\right), 3.73-4.11\left(\mathrm{~m}, 3 \mathrm{H}, \mathrm{CH}, \mathrm{NCH}_{2}\right), 4.18\left(\mathrm{q}, J=7.2 \mathrm{~Hz}, 2 \mathrm{H}, \mathrm{OCH}_{2}\right)$, 7.12 - $7.46(\mathrm{~m}, 5 \mathrm{H}, \mathrm{Ph}) ;{ }^{13} \mathrm{C} \mathrm{NMR}\left(\mathrm{CDCl}_{3}\right): 14.1\left(\mathrm{CH}_{3}\right), 38.0\left(\mathrm{CH}_{2}\right), 45.6(\mathrm{CH}), 51.6\left(\mathrm{CH}_{2} \mathrm{~N}\right), 61.2$ $\left(\mathrm{CH}_{2} \mathrm{O}\right), 119.0(\mathrm{C} \equiv \mathrm{N}), 127.6,128.4,128.6,138.0(\mathrm{Ph}), 169.2(\mathrm{C}=\mathrm{O}) ;{ }^{15} \mathrm{~N}$ NMR $\left(\mathrm{DMSO}-\mathrm{d}_{6}\right)$ : 338.5, -130.8 ppm. IR ( $\left.\mathrm{cm}^{-1}\right): v 2230(\mathrm{C} \equiv \mathrm{N}), 1734(\mathrm{C}=\mathrm{O}) . \mathrm{MS}(\mathrm{EI}), \mathrm{m} / \mathrm{z}(\%): 232\left[\mathrm{M}^{+}, 6\right], 175$ (34), 159 (65), 104 (23), 92 (30), 91 (100), 77 (28), 65 (23). Calculated for $\mathrm{C}_{13} \mathrm{H}_{16} \mathrm{~N}_{2} \mathrm{O}_{2}$ : C 67.22; H 6.94; N 12.06. Found: C 67.30; H 6.93; N 12.05.

\section{Ethyl 2-(benzylamino)-3-cyanopropanoate 4cb}

Colourless oil, 75 mg, 32\% yield; ${ }^{1} \mathrm{H}$ NMR $\left(\mathrm{CDCl}_{3}\right)$ : 1.29 (t, $\left.J=7.1 \mathrm{~Hz}, 3 \mathrm{H}, \mathrm{CH}_{3}\right), 2.18(\mathrm{~s}, 1 \mathrm{H}$, $\mathrm{NH}), 2.59-2.76\left(\mathrm{~m}, 2 \mathrm{H}, \mathrm{CH}_{2}\right), 3.53(\mathrm{t}, J=6.3 \mathrm{~Hz}, 1 \mathrm{H}, \mathrm{NCH}), 3.71-3.91(\mathrm{dd}, J=35.1,13.2 \mathrm{~Hz}$, $\left.2 \mathrm{H}, \mathrm{NCH}_{2}\right), 4.23\left(\mathrm{dq}, J=7.2,2.1 \mathrm{~Hz}, 2 \mathrm{H}, \mathrm{OCH}_{2}\right), 7.18-7.40(\mathrm{~m}, 5 \mathrm{H}, \mathrm{Ph}) ;{ }^{13} \mathrm{C} \mathrm{NMR}\left(\mathrm{CDCl}_{3}\right)$ : $14.2\left(\mathrm{CH}_{3}\right), 22.2\left(\underline{\mathrm{CH}}_{2} \mathrm{C} \equiv \mathrm{N}\right), 51.8\left(\mathrm{CH}_{2} \mathrm{~N}\right), 56.5(\mathrm{CHN}), 61.9\left(\mathrm{OCH}_{2}\right), 116.8(\mathrm{C} \equiv \mathrm{N}), 127.5,128.3$, 128.6, $138.9(\mathrm{Ph}), 171.7(\mathrm{C}=\mathrm{O}) ;{ }^{15} \mathrm{~N}$ NMR $\left(\mathrm{CDCl}_{3}\right):-336.8,-131.5 \mathrm{ppm} . \mathrm{IR}\left(\mathrm{cm}^{-1}\right): v 1193(\mathrm{C}-\mathrm{N})$, 
$1734(\mathrm{C}=\mathrm{O}) . \mathrm{MS}(\mathrm{EI}), \mathrm{m} / \mathrm{z}(\%): 232\left[\mathrm{M}^{+},<1\right], 159$ (20), 106 (19), 91 (100). Calculated for $\mathrm{C}_{13} \mathrm{H}_{16} \mathrm{~N}_{2} \mathrm{O}_{2}$ : C 67.22; H 6.94; N 12.06. Found: C 67.26; H 6.94; N 11.69.

\section{Methyl (2S,3S)-3-cyano-2-morpholino-3-phenylpropanoate 4ea}

Colourless cubic crystals, $87 \mathrm{mg}, 64 \%$ yield; mp $110^{\circ} \mathrm{C} ;{ }^{1} \mathrm{H} \mathrm{NMR}\left(\mathrm{CDCl}_{3}\right): \delta 2.48-2.60(\mathrm{~m}, 2 \mathrm{H}$, $\left.\mathrm{N}\left(\mathrm{CH}_{2}\right)_{2}\right), 2.72-2.84\left(\mathrm{~m}, 2 \mathrm{H}, \mathrm{N}\left(\mathrm{CH}_{2}\right)_{2}\right), 3.50-3.59\left(\mathrm{~m}, 4 \mathrm{H}, \mathrm{CH}_{3}, \mathrm{NCH}\right), 3.66-3.82(\mathrm{~m}, 4 \mathrm{H}$, $\left.\mathrm{O}\left(\mathrm{CH}_{2}\right)_{2}\right) 4.31(\mathrm{~d}, J=10.9 \mathrm{~Hz}, 1 \mathrm{H}, \mathrm{CCH}), 7.26-7.38(\mathrm{~m}, 5 \mathrm{H}, \mathrm{Ph}) ;{ }^{13} \mathrm{C} \mathrm{NMR}\left(\mathrm{CDCl}_{3}\right): \delta 38.6$ $(\mathrm{C} \underline{\mathrm{CH}}), 50.5(\mathrm{NCH}), 51.7\left(\mathrm{CH}_{3}\right), 67.3\left(\mathrm{~N}\left(\mathrm{CH}_{2}\right)_{2}\right), 71.3\left(\mathrm{O}_{\left.\left(\mathrm{CH}_{2}\right)_{2}\right),} 119.0(\mathrm{C} \equiv \mathrm{N}), 128.7,128.9\right.$, 129.3, $132.6(\mathrm{Ph}), 168.0(\mathrm{C}=\mathrm{O})$. IR $\left(\mathrm{cm}^{-1}\right): v 1165,1734(\mathrm{C}=\mathrm{O}), 2247(\mathrm{C} \equiv \mathrm{N}) . \mathrm{MS}(\mathrm{EI}), \mathrm{m} / \mathrm{z}(\%)$ : 158 (100), 116 (27). Calculated for $\mathrm{C}_{15} \mathrm{H}_{18} \mathrm{~N}_{2} \mathrm{O}_{3}$ : C 65.68; $\mathrm{H} 6.61 ; \mathrm{N} \mathrm{10.21.} \mathrm{Found:} \mathrm{C}$ 65.52; $\mathrm{H}$ $6.58 ; \mathrm{N} 10.03$.

Methyl 3-cyano-2-morpholino-3-phenylpropanoate 4ea (mixture of diastereomers 55:45) ${ }^{1} \mathrm{H} \mathrm{NMR}\left(\mathrm{CDCl}_{3}\right): \delta 2.48-2.60(2.29-2.37)\left(\mathrm{m}, 2 \mathrm{H}, \mathrm{N}\left(\mathrm{CH}_{2}\right)_{2}\right), 2.72-2.84(2.65-2.73)(\mathrm{m}, 2 \mathrm{H}$, $\left.\mathrm{N}\left(\mathrm{CH}_{2}\right)_{2}\right), 3.45-3.55(3.67-3.75)(\mathrm{m}, 1 \mathrm{H}, \mathrm{NCH}), 3.55(3.74)\left(\mathrm{s}, 3 \mathrm{H}, \mathrm{CH}_{3}\right), 3.66-3.82(3.44-3.51)$ $\left(\mathrm{m}, 4 \mathrm{H}, \mathrm{O}\left(\mathrm{CH}_{2}\right)_{2}\right) 4.31(4.17)(\mathrm{d}, J=10.9 \mathrm{~Hz},(J=9.4 \mathrm{~Hz}), 1 \mathrm{H}, \mathrm{CCH}), 7.26-7.38(7.26-7.38)$ (m, 5H, Ph); ${ }^{13} \mathrm{C}$ NMR $\left(\mathrm{CDCl}_{3}\right): \delta 38.6(37.3)(\mathrm{C} \underline{\mathrm{CH}}), 50.5(50.4)(\mathrm{NCH}), 51.7(52.0)\left(\mathrm{CH}_{3}\right), 67.3$ (67.0) $\left(\mathrm{N}\left(\mathrm{CH}_{2}\right)_{2}\right), 71.3(71.3)\left(\mathrm{O}\left(\mathrm{CH}_{2}\right)_{2}\right), 119.0(119.3)(\mathrm{C} \equiv \mathrm{N}), 128.7(128.6), 128.9(129.0), 129.3$ (129.2), $132.6(132.9)(\mathrm{Ph}), 168.0(168.8)(\mathrm{C}=\mathrm{O}) \mathrm{ppm} . \mathrm{IR}\left(\mathrm{cm}^{-1}\right): v 1165,1734(\mathrm{C}=\mathrm{O}), 2247$ $(\mathrm{C} \equiv \mathrm{N}) . \mathrm{MS}(\mathrm{EI}), \mathrm{m} / \mathrm{z}(\%): 158$ (100), 59 (18). Calculated for $\mathrm{C}_{15} \mathrm{H}_{18} \mathrm{~N}_{2} \mathrm{O}_{3}$ : C 65.68; H 6.61; N 10.21. Found: C 65.53; H 6.60; N 10.03.

Methyl 2-(benzylamino)-3-cyano-3-phenylpropanoate 4eb (55:45 mixture of diastereomers) Pale yellow oil, $110 \mathrm{mg}, 75 \%$ yield; ${ }^{1} \mathrm{H}$ NMR $\left(\mathrm{CDCl}_{3}\right): \delta 2.17$ (1.96) (br.s, $\left.1 \mathrm{H}, \mathrm{NH}\right), 3.56(3.61)$ $\left(\mathrm{s}, 3 \mathrm{H}, \mathrm{CH}_{3}\right), 3.55-3.71(3.55-3.71)\left(\mathrm{m}, 2 \mathrm{H}, \mathrm{NCH}, \mathrm{NCH}_{2}\right), 3.74(3.83)(\mathrm{d}, J=13.2 \mathrm{~Hz},(J=13.2$ $\left.\mathrm{Hz}), 1 \mathrm{H}, \mathrm{NCH}_{2}\right), 4.08(4.19)(\mathrm{d}, J=5.1 \mathrm{~Hz},(J=6.5 \mathrm{~Hz}), 1 \mathrm{H}, \mathrm{CCH}), 7.10-7.36(7.10-7.36)(\mathrm{m}$, 
10H, Ph); ${ }^{13} \mathrm{C}$ NMR $\left(\mathrm{CDCl}_{3}\right): \delta 42.0(41.3)(\mathrm{CCH}), 52.2(52.3)(\mathrm{NCH}), 52.4(52.5)\left(\mathrm{CH}_{3}\right), 64.1$ (63.1) $\left(\mathrm{NCH}_{2}\right), 118.6(118.8)(\mathrm{C} \equiv \mathrm{N}), 127.4,127.5,128.2,128.3,128.4,128.5,128.6,128.8,128.9$, 129.0, 129.1, 131.4, 132.5, 138.8, $138.9(\mathrm{Ph}), 172.0(171.4)(\mathrm{C}=\mathrm{O}) .{ }^{15} \mathrm{~N} \mathrm{NMR}\left(\mathrm{CDCl}_{3}\right):-339.3(-$ 340.7) $(\mathrm{NH}),-129.3(-129.3)(\mathrm{C} \equiv \mathrm{N}) \mathrm{ppm} . \mathrm{IR}\left(\mathrm{cm}^{-1}\right): v 1203,1738(\mathrm{C}=\mathrm{O}), 2245(\mathrm{C} \equiv \mathrm{N}) . \mathrm{MS}(\mathrm{EI})$, m/z (\%): 178 (22), 91 (100). Calculated for $\mathrm{C}_{18} \mathrm{H}_{18} \mathrm{~N}_{2} \mathrm{O}_{2}$ : C 73.45; H 6.16; N 9.52. Found: C 73.33; H 6.12; N 9.67.

\section{Synthesis of adduct 5 .}

The solution of morpholine $\mathbf{2 a}(1 \mathrm{mmol})$ in ethanol $(2 \mathrm{~mL})$ was added to $1 \mathrm{mmol}$ of enoate $\mathbf{1 e}$. This mixture was placed in a tube and sealed. Than it was heated to $100^{\circ} \mathrm{C}$ for $5 \mathrm{~h}$. The reaction mixture was concentrated in vacuo and the crude product was purified by column chromatography (silica gel, eluent ether/hexane).

\section{Ethyl 3-cyano-4-morpholinobutanoate 5fa}

Colourless oil, $54 \mathrm{mg}, 24 \%$ yield; ${ }^{1} \mathrm{H} \mathrm{NMR}\left(\mathrm{CDCl}_{3}\right): \delta 1.24\left(\mathrm{t}, J=7.1 \mathrm{~Hz}, 3 \mathrm{H}, \mathrm{CH}_{3}\right), 2.40-2.56$ $\left(\mathrm{m}, 5 \mathrm{H}, \mathrm{N}\left(\mathrm{CH}_{2}\right)_{2}, \mathrm{CCH}_{2}, \mathrm{NCH}_{2}\right), 2.56-2.72\left(\mathrm{~m}, 3 \mathrm{H}, \mathrm{N}\left(\mathrm{CH}_{2}\right)_{2}, \mathrm{NCH}_{2}\right), 3.10-3.20(\mathrm{~m}, 1 \mathrm{H}, \mathrm{CH})$, $3.56-3.70\left(\mathrm{~m}, 4 \mathrm{H}, \mathrm{O}\left(\mathrm{CH}_{2}\right)_{2}\right), 4.15\left(\mathrm{q}, J=7.1 \mathrm{~Hz}, 2 \mathrm{H}, \mathrm{CH}_{2}\right) ;{ }^{13} \mathrm{C} \mathrm{NMR}\left(\mathrm{CDCl}_{3}\right): \delta 14.2\left(\mathrm{CH}_{3}\right)$, $26.0(\mathrm{CH}), 34.8\left(\mathrm{CCH}_{2}\right), 53.7\left(\mathrm{NCH}_{2}\right), 59.3\left(\mathrm{~N}\left(\mathrm{CH}_{2}\right)_{2}\right), 61.4\left(\mathrm{OCH}_{2} \mathrm{CH}_{3}\right), 66.9\left(\mathrm{O}_{\left.\left(\mathrm{CH}_{2}\right)_{2}\right),}, 20.6\right.$ $(\mathrm{C} \equiv \mathrm{N}), 170.0(\mathrm{C}=\mathrm{O}) \mathrm{ppm} . \mathrm{IR}\left(\mathrm{cm}^{-1}\right): v 1118,1191,1735(\mathrm{C}=\mathrm{O}), 2244(\mathrm{C} \equiv \mathrm{N}) . \mathrm{MS}(\mathrm{EI}), \mathrm{m} / \mathrm{z}(\%)$ : $226\left[\mathrm{M}^{+},<1\right], 100$ (100), 42 (16). HRMS Calculated for $\left[\mathrm{C}_{11} \mathrm{H}_{18} \mathrm{~N}_{2} \mathrm{O}_{3}+\mathrm{H}\right]^{+}: \mathrm{m} / \mathrm{z}=227.139568$. Found: $\mathrm{m} / \mathrm{z}=227.13903$.

\section{Acknowledgements}

The spectral and analytical data were obtained using the equipment of the Baikal analytical centre for collective use SB RAS to which authors are grateful. The high pressure experiments have been 
run under the supervision of Dr Julien Legros and Prof. Isabelle Chataigner (CNRS \& University of Rouen Normandie) who are acknowledged for their advices and help.

\section{References}

[1] For the recent reviews, see: a) J. Gmach, Ł. Joachimiak, K. M. Błażewska, Synthesis 2016, 48, 2681-2704; b) A. Yu. Rulev, Russ. Chem. Rev. 2011, 80, 197-218; c) A. Yu. Rulev, Russ. Chem. Bull. 2016, 65, 1687-1699; d) A. Yu. Rulev, Eur. J. Org. Chem. 2018, 2018, 3609-3617.

[2] J. S. Carey, D. Laffan, C. Thomson, M. T. Williams, Org. Biomol. Chem. 2006, 4, $2337-$ 2347.

[3] A. Yu. Rulev, N. Yenil, A. Pesquet, H. Oulyadi, J. Maddaluno, Tetrahedron 2006, 62, 54115416.

[4] A. Yu. Rulev, S. Azad, H. Kotsuki, J. Maddaluno, Eur. J. Org. Chem. 2010, 2010, 64236429.

[5] a) V. M. Vlasov. Monatsh. Chem. 2016, 147, 319-328; b) I.-H. Um, J.-S. Kang, J.-Y. Park. J. Org. Chem. 2013, 78, 5604-5610.

[6] a) L. R. Domingo, A. Seif, E. Mazarei, E. Zahedi, T. S. Ahmadi. New J. Chem. 2020, 44, 19002-19012; b) T. A. Hamlin, I. Fernández, F. M. Bickelhaupt. Angew. Chem. Int. Ed. 2019, 58, 8922-8926.

[7] R. Le Goff, A. M. Lawson, A. Daïch, S. Comesse, Org. Biomol. Chem. 2013, 11, 18181821.

[8] A. Yu. Rulev, RSC Adv. 2014, 4, 26002-26012.

[9] E. Lewandowska, K. Wichlacz, A. J. Sobczak, Tetrahedron 2010, 66, 152-156.

[10] R. Ballini, N. A. Bazán, G. Bosica, A. Palmieri, Tetrahedron Lett. 2008, 49, 3865-3867.

[11] R. Ballini, S. Gabrielli, A. Palmieri, Synlett 2009, 965-967.

[12] R. Ballini, S. Gabrielli, A. Palmieri, Curr. Org. Chem. 2010, 14, 65-83. 
[13] J. C. Anderson, A. S. Kalogirou, G. J. Tizzard, Tetrahedron 2014, 70, 9337-9351.

[14] V. V. Pelipko, Reactions of alkyl-3-nitro- and 3-bromo-3-nitroacrylates with cyclic CHacids and 1,4-binucleophilic reagents. $\mathrm{PhD}$ thesis, Saint-Petersburg State Institute of Technology (Russia), 2019.

[15] S. Gabrielli, E. Chiurchiù, A. Palmieri, Adv. Synth. Catal. 2019, 361, 630-653.

[16] V. V. Pelipko, I. S. Adyukov, R. I. Baichurin, S. V. Makarenko, Russ J. Gen. Chem. 2020, 90, 493-494.

[17] D. Berkeš, A. Koreňová, P. Šafár̆, H. Horváthová, N. Prónayová, Centr. Eur. J. Chem. 2007, 5, 688-705.

[18] N. N. Kolos, A. A. Tishchenko, V. D. Orlov, T. B. Berezkina, S. V. Shishkina, O. V. Shishkin, Chem. Heterocycl. Comp. 2001, 37, 1289-1295.

[19] C. Barberot, A. Moniot, I. Allart-Simon, L. Mallert, T. Egorova, M. Laronze-Cochard, A. Bentaher, M. Medebielle, J.-P. Bouillon, E. Hénon, J. Sapi, F. Velard, S. Gérard, Eur. J. Med. Chem. 2018, 146, 139-146.

[20] M. Molteni, A. Volonterio, G. Fossati, P. Lazzari, M. Zanda, Tetrahedron Lett. 2007, 48, 589-593.

[21] A. Fedotova, B. Crousse, I. Chataigner, J. Maddaluno, A. Yu. Rulev, J. Legros, J. Org. Chem. 2015, 80, 10375-10379.

[22] I. N. Zubkov, A. R. Romanov, I. A. Ushakov, A. Yu. Rulev, Tetrahedron 2020, 76, 130884.

[23] P. Zaderenko, M. C. López, P. Ballestros, J. Org. Chem. 1996, 61, 6825-6828.

[24] A. Yu. Rulev, J. Maddaluno, G. Plé, J-C. Plaquevent, L. Duhamel, J. Chem. Soc., Perkin Trans. 1 1998, 1397-1401.

[25] A. Yu. Rulev, J. Maddaluno, Eur. J. Org. Chem. 2001, 2001, 2569-2576.

[26] A. Yu. Rulev, H. Kotsuki, J. Maddaluno, Green Chem. 2012, 14, 503-508.

[27] A. Yu. Rulev, J. Maddaluno, J. Phys. Org. Chem. 2002, 15, 590-598. 
[28] F. Dumas, B. Mezrhab, J. d'Angelo, C. Riche, A. Chiarone, J. Org. Chem. 1996, 61, 22932304.

[29] I. Chataigner, C. Panel, H. Gérard, S. R. Piettre, Chem. Comm. 2007, 3288-3290.

[30] D. S. Allgäuer, H. Jangra, H. Asahara, Z. Li, Q. Chen, H. Zipse, A. R. Ofial, H. Mayr, J. Am. Chem. Soc. 2017, 139, 13318-13329.

[31] L. R. Domingo, M. Rios-Gutiérrez, P. Pérez. Molecules 2016, 21, 748.

[32] For selected articles, see: a) P. K. Chattaraj, S. Duley, L. R. Domingo, Org. Biomol. Chem. 2012, 10, 2855-2861; b) L. R. Domingo, P. Pérez, J. A. Sáez, RSC Adv. 2013, 3, 14861494; c) R. G. Parr, W. Yang, J. Amer. Chem. Soc. 1984, 106, 4049-4050; d) R. G. Parr, L. von Szentpály, S. Liu, J. Amer. Chem. Soc. 1999, 121, 1922-1924; e) J. L. Gázquez, J. Mex. Chem. Soc. 2008, 52, 3-10.

[33] T. Lu, F. W. Chen, J. Comput. Chem. 2012, 33, 580-592.

[34] R. R. Contreras, P. Fuentealba, M. Galvan, P. Perez, Chem. Phys. Lett. 1999, 304, 405413.

[35] P. K. Chattaraj, U. Sarkar, D. R. Roy, Chem. Rev. 2006, 106, 2065-2091.

[36] K. J. Fukui, J. Chem. Phys. 1952, 20, 722-725.

[37] K. J. Fukui, J. Chem. Phys. 1954, 22, 1433-1442.

[38] J. Olah, C. Van Alsenoy, A. B. Sannigrahi, J. Phys. Chem. A 2002, 106, 3885-3890.

[39] L. R. Domingo, P. Perez, Org. Biomol. Chem. 2011, 9, 7168-7175.

[40] S. Pratihar, S. Roy, J. Org. Chem. 2010, 75, 4957-4963.

[41] L. R. Domingo, E. Chamorro, P. Perez, J. Org. Chem. 2008, 73, 4615-4624.

[42] J. Tomasi, B. Mennucci, E. Cancès, J. Mol. Struct.: THEOCHEM 1999, 464, 211-226.

[43] U. Olsher, R. M. Izatt, J. S. Bradshaw, N. K. Dalley, Chem. Rev. 1991, 91, 137-164.

[44] GAUSSIAN 09, Revision C.01. M. J. Frisch, G. W. Trucks, H. B. Schlegel, G. E. Scuseria, M. A. Robb, J. R. Cheeseman, G. Scalmani, V. Barone, B. Mennucci, G. A. Petersson, H. Nakatsuji, M. Caricato, X. Li, H. P. Hratchian, A. F. Izmaylov, J. Bloino, G. Zheng, J. L. 
Sonnenberg, M. Hada, M. Ehara, K. Toyota, R. Fukuda, J. Hasegawa, M. Ishida, T. Nakajima, Y. Honda, O. Kitao, H. Nakai, T. Vreven, J. A. Montgomery Jr., J. E. Peralta, F. Ogliaro, M. Bearpark, J. J. Heyd, E. Brothers, K. N. Kudin, V. N. Staroverov, R. Kobayashi, J. Normand, K. Raghavachari, A. Rendell, J. C. Burant, S. S. Iyengar, J. Tomasi, M. Cossi, N. Rega, J. M. Millam, M. Klene, J. E. Knox, J. B. Cross, V. Bakken, C. Adamo, J. Jaramillo, R. Gomperts, R. E. Stratmann, O. Yazyev, A. J. Austin, R. Cammi, C. Pomelli, J. W. Ochterski, R. L. Martin, K. Morokuma, V. G. Zakrzewski, G. A. Voth, P. Salvador, J. J. Dannenberg, S. Dapprich, A. D. Daniels, Ö. Farkas, J. B. Foresman, J. V. Ortiz, J. Cioslowski, D. J. Fox, Gaussian, Inc., Wallingford CT, USA (2009). See http:// http://www.gaussian.com. Last visit 26 September 2020.

[45] A. D. Becke, J. Chem. Phys. 1993, 98, 5648-5652.

[46] C. Lee, W. Yang, R. G. Parr, Phys. Rev. B 1988, 37, 785-789.

[47] T. H. Dunning, Jr., J. Chem. Phys. 1989, 90, 1007-1023. 


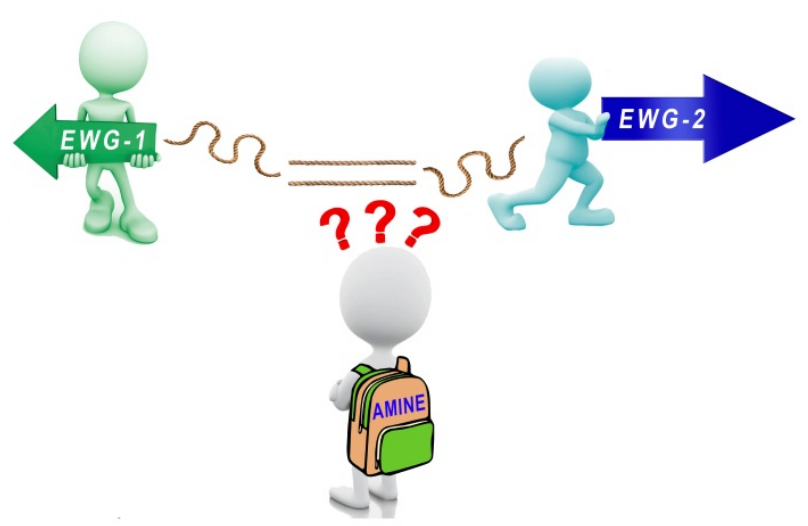

A. Rulev, *I. Zubkov, I. Ushakov, V. Semenov, A. Vashchenko, J. Maddaluno*

Regioselectivity of the conjugate addition of amines to dissymmetrical pull-pull alkenes

The regioselectivity of the conjugate nucleophilic addition of amines to vicinal di-acceptor-substituted alkenes has been studied. The inverse local electrophilicity indices give good account on the reactivity of the competitive electrophilic sites. 